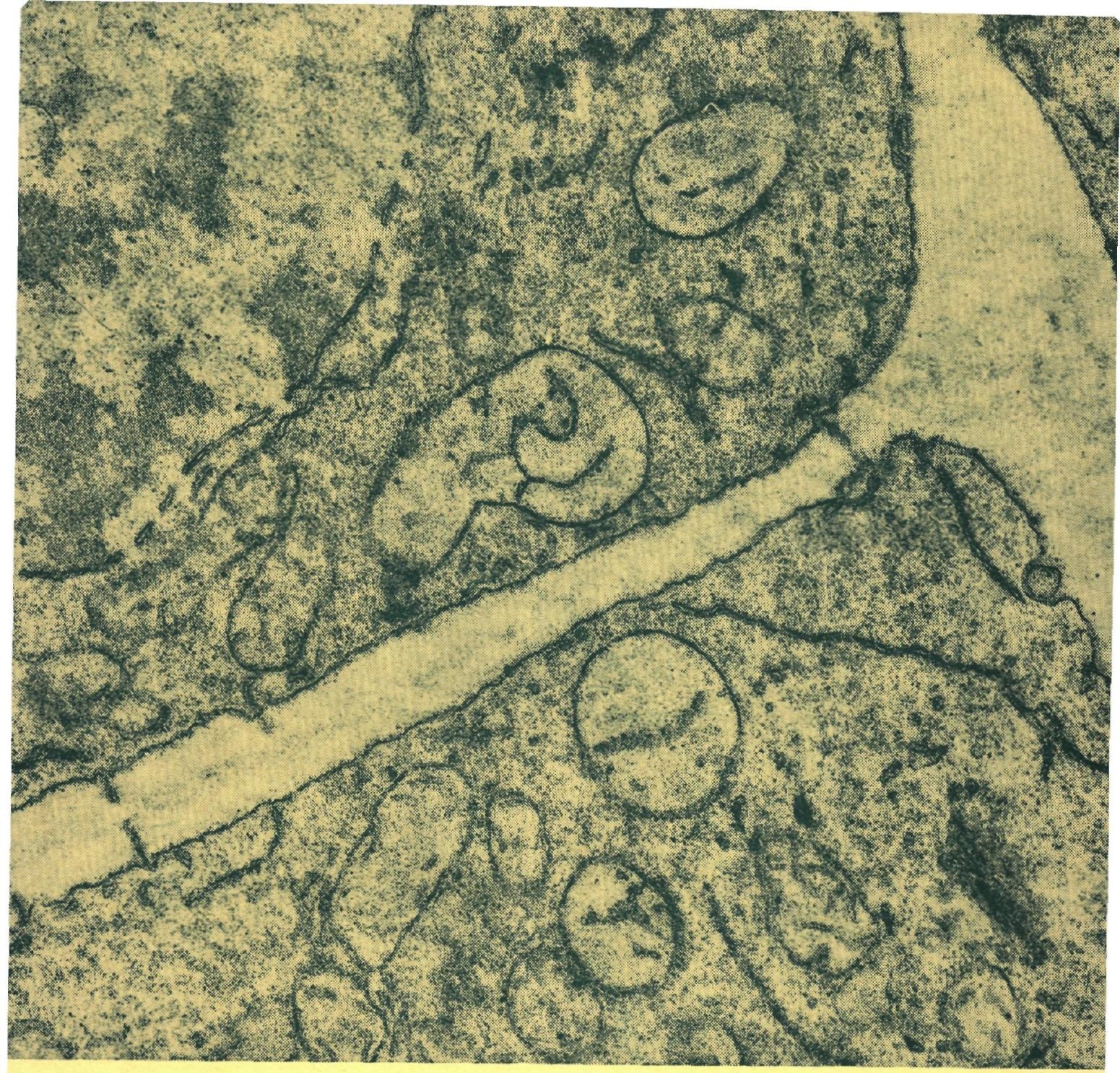

\title{
BREAKDOWN OF THE PLANT CELL WALL DURING THE CELL-FUSION PROCESS
}





BREAKDOWN OF THE PLANT CELL WALL DURING THE GELL-FUSION PROGESS 
Promotor: Prof. DR. H. F. Linskens 


\section{BREAK DOWN OF THE PLANT CELL WALL DURING THE CELL-FUSION PROCESS}

\section{PROEFSCHRIFT}

TER VERKRIJGING VAN DE GRAAD VAN DOCTOR IN DE WISKUNDE EN NATUURWETENSCHAPPEN AAN DE KATHOLIEKE UNIVERSITEIT TE NIJMEGEN OP GEZAG VAN DE RECTOR MAGNIFICUS DR. W. J. M. A. ASSELBERGS, HOOGLERAAR IN DE FAGULTEIT DER LETTEREN, VOLGENS HET BESLUIT VAN DE SENAAT IN HET OPENBAAR TE VERDEDIGEN OP MAANDAG 5 JULI 1965 DES NAMIDDAGS TE 4 UUR

DOOR

\section{MARIE MATHIAS ANDREAS SASSEN}

GEBOREN TE GELEEN

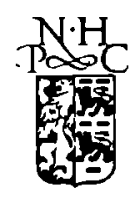

1965

NORTH-HOLLAND PUBLISHINGG COMPANY - AMSTERDAM 

Aan mijn Ouders 



\title{
BREAKDOWN OF THE PLANT CELL WALL DURING THE CELL-FUSION PROCESS
}

\author{
M. M. A. SASSEN
}

(Department of Botany, University, Nijmegen, The Netherlands)

(received March 31st, 1965)

\begin{abstract}
The disappearance of cell walls during the cell fusion process in the plant was studied electron microscopically on the following objects.

Hordeum vulgare. Differentiation in the central vessel of the root.

Achras sapota Origin of laticifers in the shoot apex.

Phycomyces blakesleeanus and Hansenula winger: Zygote formation.

In the central vessel of Hordeum the end wall first swells, it is then detached in its entirety from the lateral wall, after which the breakdown process is completed.

In Achras, Phycomyces and Hansenula cell wall breakdown durıng the cell fusion process takes place gradually, beginnung in the centre. Enzymes that are in close contact with the plasma membrane probably play a part in this process.

Both the skeleton which consists of microfibrils and the matrix of the cell walls are dissolved enzymatically. A cellulolytic enzyme is demonstrated in the root extract of Hordeum, a chitinolytic enzyme in the zygote extract of Phycomyces.
\end{abstract}

\section{CONTENTS}

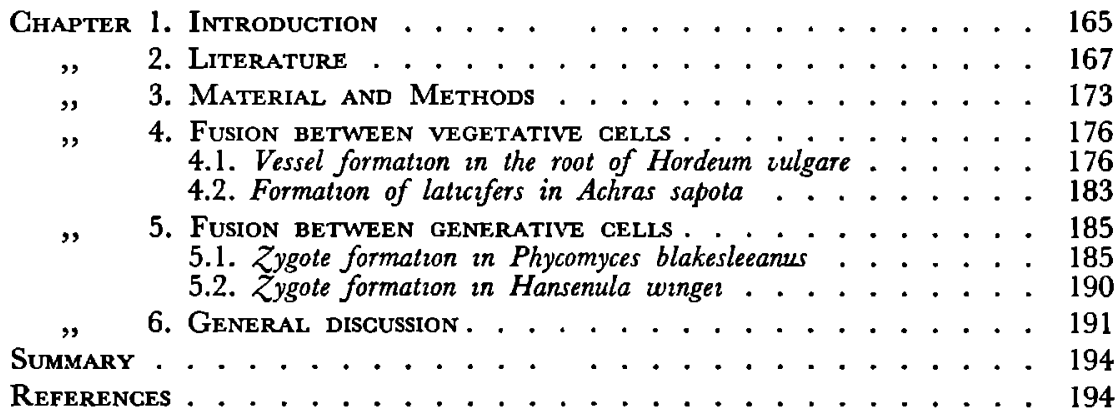

\section{CHAPTER 1}

\section{INTRODUCTION}

The cell wall develops as the plant grows; in the living plant, the breakdown of the cell wall associated with cell fusion occurs only during differentiation. As a result of the disappearance of one or more cell walls or parts of them fusions occur between the cells in question. In consequence of this a fusion of the protoplasts may 
take place, as is the case in the formation of zygotes, sieve tubes and laticifers, or the protoplasm may disappear altogether, so that long tubes are formed, as in the formation of xylem vessels. By cell fusion we here understand the fusion of two or more cells into one unit, during which process the cell walls with which the cells touch each other are broken down either completely or partially. The relatively much smaller pores in the cell walls, which contain the plasmodesmata, do not fall under this subject. Indeed these pores are present from the formation of the cell wall and are consequently not formed through breakdown. In studying the cell wall which is involved in the fusion we can distinguish two types:

1. Cell fusions which take place between cells which, from their formation onwards, have lain next to each other in tissue connection. These cells may be denoted by means of the term "sister cells". After originating from the mother cell the protoplasts of these sister cells have been in contact with each other via the plasmodesmata. Where the same tissue is concerned the cell wall is bounded on both sides by similar protoplasm. In such cases this cell wall consists of a middle lamella with a primary wall on either side. Before the fusion this wall may undergo changes.

2. Cell fusions which take place between two cells which just come into contact with each other during the fusion. There are no connections between the protoplasts in this case, nor do they have to be similar. The cell walls, too, are fused here, hence we can speak of the fusion wall. The fusion wall is then differently built up. A middle lamella is lacking. Before the fusion both cells consist of a complete cell wall, which may be surrounded on the outside by a cuticle. The cells and consequently the walls as well may grow still further before the fusion takes place. The way in which such cells come into contact with each other is of great importance to fertilization physiology, but will not be discussed here.

It is also possible to divide cell fusions into those which take place between vegetative cells and those in which generative cells are involved. In the above classification the fusions between vegetative cells may be put under 1 , those between generative cells under 2 . However, this comparison does not hold good in all cases. For example, hyphal anastomoses are fusions between vegetative cells; as far as the fusion wall is concerned, however, they are fusions which take place as a result of cells meeting each other for the first time and in the above classification they should consequently be put under 2 . During the fertilization process in higher plants a complex system of cell fusions occurs, which should partly be classified under 1 and partly under 2 . In connection with this study, only those cell fusions in which the cells involved possess cell walls are important. The classification into fusions between vegetative and generative cells will be kept up. 
Chapter 2

\section{LITERATURE}

\subsection{Fusions between vegetative cells}

\subsubsection{Xylem vessels}

Differentiation in xylem vessels has already been studied in detail. Attention has again been drawn to this field by the use of the electron microscope. During the formation of xylem vessels the transverse walls or end walls are broken down completely or partially. As far as the primary xylem is concerned, this breakdown takes place during differentiation, therefore in the meristem. Esau and HewITT (1940) survey the older literature concerning the differentiation of xylem vessels. In it particular attention is paid to the problem of the secondary thickenings and the moment of disintegration of the protoplasm and nucleus. Concerning the thickening of the end wall EAMEs and MacDaniels (1925 p. 151) are of the opinion that it is secondary in nature. FLACH (1924) and EsAu (1936) regard it as a primary thickening. But little information is available concerning the disappearance of the end wall. It is generally accepted that the disappearance of the end wall is a process which gradually extends over the whole wall. According to FLACH (1924) the thinning down starts somewhere in the centre of the wall, and the resorption is probably brought about by the action of enzymes, which are formed or activated by the disintegrating protoplast. This process, once started, must proceed very rapidly, since a disintegrating end wall was seldom observed.

EsAU (1936) assumes a gradual thinning down of the end wall, until finally there are only thin threads left, which afterwards disappear as well. She goes on to say: "The thinning down of the end wall seems to indicate that it is dissolved." And further: "In many sections the end wall is broken in cutting on the microtome. In such cases the fragments may become tilted." Quite a different explanation is given by PRIESTLy et al. (1935) who assume that the end walls are destroyed mechanically during the growth of the cells. They assume that the end walls break in the centre and rapidly contract, forming a rim along the lateral wall. For the rest they suggest that the perforation takes place very quickly, since stages of this process have never been observed.

EsAu and HewitT (1940), in a later study of the structure of the end walls during the differentiation in xylem vessels, mention nothing new about the breakdown process. Like Flach (1924) and Duerden (1934), they report that the stages in the disintegration of end walls have seldom been observed.

ScotT et al. (1960) write about this in connection with their investigation of the primary xylem of Ricinus communis: "The internal lining of the vessel becomes more clearly defined, and as the protoplast becomes moribund, the vessel-end wall presumably disintegrates and 
is resorbed" and further in the same paper: "Stages in the disintegration of the end walls were not observed." From this it appears that they have observed nothing of the disintegration process and that they assumc that the end wall during the disintegration of the protoplast is broken up into pieces and resorbed. Scott's investigation was carried out with the electron microscope on shadow-cast material.

EsAU et al. (1963), by means of thin sections, investigated the fine structure of xylem vesscls of Cucurbita during differentiation. Apart from changes in the cytoplasm they also describe the end wall here. It contains plasmodesmata and has become considerably thicker before it is broken down. Esau (1936) called this thickening a swelling phenomenon, but her electron microscopic investigation has not contributed anything to its interpretation.

Buvat (1964a, 1964b, 1964c) has dealt extensively with the differentiation in xylem vessels. Here (1964a) he describes the changes that occur in the protoplasm: the nucleus becomes larger and the membranes of the endoplasmic reticulum, both rough and smooth, increase considerably. It is striking that this endoplasmic reticulum forms many anastomoses. Most conspicuous is the enormous development of vesicles originating from Golgi-bodies. Mitochondria are of the usual type. Plastids are present, but they do not contain any starch. The plastids become hypertrophied and degenerate. The vacuoles merge into one big vacuole and in the end the whole protoplasm disappears, leaving some membrane fragments behind.

Buvat (1964b) describes the formation of secondary thickenings on the lateral walls of the metaxylem vessels. These thickenings are supposed to originate through excretion of the contents of vesicles from the endoplasmic reticulum and Golgi-bodies.

Buvat (1964c) describes the differentiation of the end walls before they are dissolved. The thickening of these walls is studied. Here, too, vesicles from Golgi-bodies are supposed to contribute to the thickening of the wall. According to Buvat this is not a simple process of imbibition of hydrophylic polysaccharides, but a passage of chemically active compounds, the function of which is controlled by the cytoplasm.

\subsubsection{Sieve tubes}

ESAU et al. (1962) mention two old theories about the origin of pores in sieve tubes. According to one the pores are derived from the plasmodesmata of the primary pitfields, either by an increase in thickness or fusion in groups into single large strands. According to the other the pore sides of the sieve plates have no plasmodesmata and the pore is supposed to originate from local removal of cell wall material. In our view the removal of cell wall material between the plasmodesmata must also take place in the case of the first theory.

FreY-Wyssling and Müller (1957), arrived at a different conclusion after an electron microscopic investigation of the cellulose skeleton of the sieve plates of Cucurbita. According to these authors 
the cellulose skeleton is not broken down during the formation of the pores but pushed aside mechanically. The matrix, however, is broken down enzymatically.

EsAU et al. (1962) have made a detailed investigation of the formation of pores in the sieve plates of a number of plants with both, the light microscope and the electron microscope. Unlike FreyWYSSLING and MüLLER (1957), who only examined cellulose skeletons they used thin sections. As a first sign of differentiation they found formation of callose platelets where pores originate afterwards. Where no callose is laid down, bars develop, which consist of cellulose fibrils and matrix. The endoplasmic reticulum has obviously a function in the formation of callose platelets, since the latter are only formed where the endoplasmic reticulum is situated along the primary wall of the future sicve plate. Plasmodesmata occur occasionally, mostly in the centre of the future pore. The callose platelets increase and the bars, too, develop further. Perforation starts in the centre of two opposite callose platelets. Part of the middle lamella is dissolved, after which the two opposite callose platelets fuse and thus form the edge of the newly-formed opening. They have not yet investigated the increase in the size of the porcs. From this work they conclude that the pores should not be regarded as enlarged plasmodesmata but as openings formed by the removal of cell wall material.

\subsubsection{Laticifers}

Of the two groups of laticifers which we can distinguish, the articulated and the non-articulated, only the former is important in connection with cell fusion. This group contains laticifers which consist of tubes running parallel to the longitudinal axis of the plant. Lateral anastomoses occur, too. They may originate in two ways, either as a result of the contact between the protuberances of two parallel tubes and the subsequent fusion of the wall, or as a result of one or more intervening cells being changed into laticifer cells. The way in which the transverse walls dissolve has already been described by many investigators, in so far as this was possible under the light microscope. The gist of this description is that the wall becomes thinner in the centre of the wall at a pit-connection (DIPPEL 1851, ScotT 1882). It is there that the first perforation of the wall occurs. Karling (1929) finds that the thinning down necd not always start in the centre and that the disappearance of the transverse wall takes place gradually. According to this author there are indications that the middle lamella resists longer than the primary wall.

\subsubsection{Hyphal anastomoses}

The hyphae of many moulds are known to anastomose. The fusion wall disappears, starting in the centre. Investigations of anastomoses in moulds were carried out by e.g. MEYER (1902), LAIBACH (1918) and KöHLER (1929). However, these authors do not give any details 
about the disappearance of the fusion wall. JAHN (1934) found that during fusion of hyphae a small pore with a diameter of 2-10 micron appears in the fusion wall.

\subsubsection{Guard cells}

In 1962 BRown and Johnson demonstrated that connecting strands occur between the guard cells of grasses. "Very close to the end of the guard-cell pair, the wall between the two cells is incomplete. The protoplasts are partially confluent and common to both cells". They further remark: "It is not known whether these walls ever had been complete during early development stages. This condition was entirely unexpected but seems to be a general condition for grasses." As we are here concerned with pores that have a diameter of about one micron, we may speak of cell fusion here, too. The openings are here reminiscent of sieve plate pores, especially because a lighter zone is visible around the "bars" (Brown and JoHnson 1962). This zone may be compared with the callose platelets round the sieve plate bars, known from the work by EsAu et al. (1962). It seems to us unlikely that these openings have been present from the origin of the guard cells.

\subsubsection{Pollen mother cells}

Investigations by CHARdARD (1962), WATERKEYN (1962), Eschrich (1963) and Heslop-HaRrison (1964) have shown that in a number of species the pollen mother cells are temporarily connected by plasma strands. It is assumed that this is a general phenomenon in pollen mother cells. According to Eschrich these pores which are found at irregular distances, have a diameter of 1 to 2,5 micron. The walls round the pores are covered with callose. These openings also resemble the pores in sieve plates (EsAu et al. 1962). The temporary openings in the walls between the pollen mother cells would justify the term cell fushion here, too.

Apart from the above cases, still more examples of cell fusions have been described. Thus Küster (1956) mentions the fusion of hyaline cells in the leaves of Sphagnum rigidum and the well-known sieve tubes in the Laminariaceae, which bear a strong resemblance to the sieve tubes in higher plants. Moreover we know about the clamp connections in Basidiomycetae. An example of this in Polystictus versicolor was described by GIRBARDT (1962). Fusions between vegetative cells have not been dealt with exhaustively here. However, from all these examples it is apparent that the disappearance of the cell walls, resulting in cell fusion, is a general phenomenon in vegetative cells.

\subsection{Fusions between generative cells}

Whenever gametes or gametangia fuse, the cell resulting from this fusion is called the zygote. 


\subsubsection{Fusion of free gametes}

When the gametes are not surrounded by other cells, as is the case in a large number of lower plants, especially moulds and algae, they can come into immediate contact and form a zygote. Zygote formation in Phycomyces blakesleeanus and other Phycomycetae was studied by e.g. BlakesLee (1904) and Ling-Young (1930). In the centre of the fusion wall an opening originates which proceeds in a centrifugal direction. Under the light microscope, too, Ling-Young observed that the remaining peripheral part of the fusion wall shows a thinning down in the direction of the breakdown area. SASSEN (1962), in a preliminary investigation with the electron microscope, showed that the fusion wall is broken down in its entirety. The enzyme required for the breakdown of the chitine skeleton could also be demonstrated in the extract of the mould.

Zygote formation in the yeast Schizosaccharomyces octosporus was studied by CoNTI and NAYLOR (1960), also with the electron microscope. From their investigation these authors conclude that the fusion wall thins down at first and is then dissolved completely, starting from the centre.

\subsubsection{Fusion of gametes surrounded by other cells}

In higher plants gametes cannot come into direct contact with each other, since they are surrounded by other cells. Thus the egg cell is formed in the embryo sac and is surrounded by synergides.

Before fertilization the sperm cells remain in the pollen tube. Before the gametes can fuse, one or more vegetative cell fusions must take place. During the penetration of the pollen tube into the embryo sac of Torenia, the first vegetative cell fusion is supposed to take place between the pollen tube and one of the synergides (v. D. Pluijm 1964). During this first fusion also, the contents of the pollen tube are emptied into the synergides, together with the sperm cells. One of these sperm cells may then fuse with the egg cell. What is important now is the question whether these two cells possess a cell wall or merely a plasma membrane. It may also be that only one of them possesses a cell wall. In the pollen grain of Petunia a cell wall is distinctly to be seen round the generative cell (SASSEN 1964a). The same holds good for Oenothera (DIERs 1963). However, no investigation has as yet been made to find out whether the two sperm cells also possess such a cell wall after the division of the generative cell. The egg cell of Torenia is known to be partly surrounded by a plasma membrane and partly by a cell wall (v. D. Pluijm 1964). This author also found that the first fusion, that between pollen tube and synergide, is in any case a fusion in which cell walls are broken down.

Where there are references to the disappearance of the cell walls that are involved in the fusion, the possibility of an enzymatic breakdown is considered. Priestly et al. (1935) take an altogether different view of this matter. They are of the opinion that this cell wall is 
destroyed mechanically during the growth of the mother cells: the cell wall breaks in the centre, after which it is thought to contract rapidly in the direction of the lateral wall. They arrive at this conclusion because they have never observed a stage in the breakdown process. Frey-Wyssuing also advances this theory in his book "Die pflanzliche Zellwand" (1959). In a chapter on "Zellfusionen" ( $p$. 75 ), this author mentions a number of examples of cell fusions and states that they originate in the same way as the primary pit fields. The microfibrils of the cellulose skeleton are pushed aside to the edge of the opening and there accumulate into a rim. The microfibrils

1 HORDEUM VULGARE

vessel formation
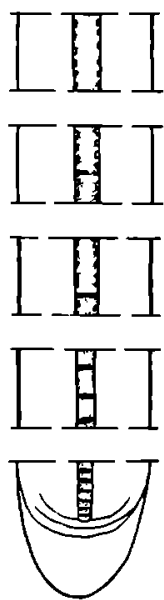

3 PHYCOMYCES BLAKESLEEARUS zygote formation

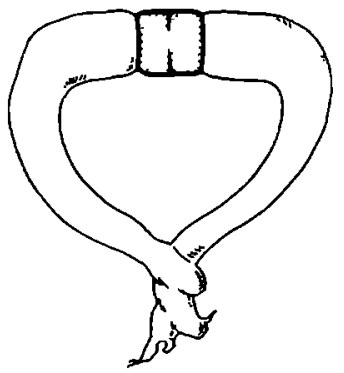

2 ACHRAS SAPOTA

formation of laticifers

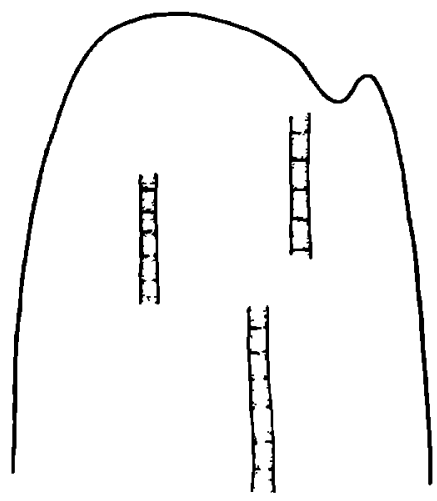

4 HANSENULA WIHGEI

zygote formation

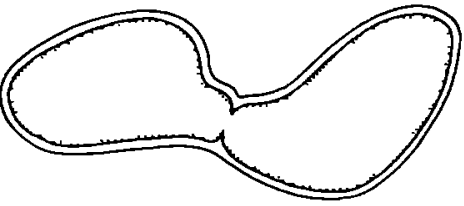

Fig. A. Schematic drawing of the plant material used, indicating the position of the cell fusions investigated. 
are consequently removed mechanically and only the remaining matrix is dissolved enzymatically. The aim of this study was to investigate the breakdown process of the cell wall during cell fusion. First of all the various stages of the breakdown process in some subjects were studied with the electron microscope. After that some enzymatic aspects of the breakdown process were also investigated and discussed. In order to obtain a survey of cell fusions in the plant kingdom two examples of cell fusions between vegetative cells and two of those between generative cells were chosen. The plant material was expected to fulfil the following conditions:

1. The fusion walls that are broken down must be relatively large.

2. The chemical composition of the fusion walls must be as different as possible.

3. The material must be suitable for examination under the electron microscope.

In order to investigate cell fusions between vegetative cells we chose roots of Hordeum vulgare (fig. A, 1) and apices of Achras sapota (fig. A, 2). In the roots of Hordeum occurs a centrally situated metaxylem vessel, which, because of its position, the size of the cells and the length of the differentiation period, seemed suitable for the investigation. The skeleton of these cells consists of cellulose and the matrix of pectin and hemicellulose, among other substances. The result of cell fusion in the root of Hordeum is a xylem vessel. In Achras sapota the laticifers are formed by cell fusion in the apical meristem. Here, too, the cell wall consists of cellulose, hemicellulose and pectin. In order to investigate the cell fusions between generative cells we chose the zygote of Phycomyces blakesleeanus (fig. A, 3) and the zygote of the yeast Hansenula wingei (fig. A, 4). Among other substances the cell wall of Phycomyces contains chitin, that of Hansenula mannan, glucan and chitin.

\section{Chapter 3}

\section{MATERIAL AND METHODS}

\subsection{Electron microscopic methods}

Thin sections were cut with glass knives on a Porter and Blum ultramicrotome and studied with a Philips E.M. 100 C. Monitor slides of 2 micron in thickness were studied by means of the phasecontrast microscope.

\subsubsection{Hordeum vulgare}

Seeds of Hordeum vulgare (grown in the botanical garden of the University) were placed on wet filter paper in Petri dishes at $27^{\circ} \mathrm{C}$. Instead of Hordeum we occasionally used Avena sativa. After four days the young plants were transferred to Hoagland and after three weeks they were harvested.

The seminal roots were cut into sections of $1 \mathrm{~mm}$, fixed for one 
hour in glutaraldehyde (SABATINI et al. 1963) in phosphate buffer

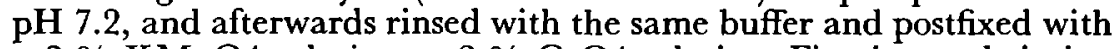
a $2 \% \mathrm{KMnO} 4$ solution or $2 \% \mathrm{OsO} 4$ solution. Fixation and rinsing took place at a temperature between $0^{\circ}$ and $4^{\circ} \mathrm{C}$. The objects were dehydrated in ethanol and transferred to Epon 812 via epoxypropane. In order to remove the epoxy-propane completely the objects were placed for some time in a vacuum of $1 \mathrm{~mm} \mathrm{Hg}$. Thin sections of the OsO4 fixed material were stained with lead citrate (REYNolds 1963). The lead citrate was stored for at least one day before use, because it was found in practice that this reduced lead carbonate contamination of the thin sections.

Prior to this, in order to direct the objects, the gelatine capsules were provided with a bottom of Epon, so that a straight surface was obtained, and polymerized at $65^{\circ} \mathrm{C}$. The capsules were then filled with Epon and the objects were placed in them. After one night at $35^{\circ} \mathrm{C}$ polymerization took place at $65^{\circ} \mathrm{G}$ for 24 hours.

In order to examine the cellulose skeleton, root pieces were treated with a mixture of hydrogen peroxide and acetic acid and embedded in methacrylate, which was dissolved again in the thin sections with amylacetate. The cellulose skeleton was then shadowed with platinum or palladium.

\subsubsection{Achras sapota}

Seeds of Achras sapota, brought from Surinam by Dr. A. L. Stoffers, were grown in the greenhouse. The apices were fixed and embedded in accordance with the method described in 3.1.1.

\subsubsection{Phycomyces blakesleeanus}

Phycomyces blakesleeanus was supplied from the collection of the Centraal Bureau voor Schimmelcultures (C.B.S.) at Baarn. Zygotes of Phycomyces were obtained by growing together $(+)$ and $(-)$ strains on malt agar in Petri dishes. After growing for four days at room temperature the zygotes were collected, fixed and embedded in accordance with the method described in 3.1.1.

\subsubsection{Hansenula wingei}

The strains 5 and 21 (Wickerham NRRL Y-2340) were also obtained from the C.B.S., from the yeast collection at Delft. For one night the two strains were grown at $27^{\circ} \mathrm{C}$ in a growth medium in Erlenmeyer flasks on the reciprocating shaker. The cells were then washed, mated in a conjugation medium, and again placed on the reciprocating shaker. After two, three and four hours samples were drawn and these were then fixed and embedded in accordance with the method described in 3.1.1. However, as fixatives for Hansenula only glutaraldehyde and $\mathrm{KMnO} 4$ were used. With slight alterations the growing method, the growth medium and the conjugation medium were taken from BROck (1961). 


\subsection{Enzymatic methods}

In order to find out if there is a cellulolytic enzyme in the roots of Hordeum and a chitinolytic enzyme in the zygotes of Phycomyces the following methods were applied.

\subsubsection{Cellulase test}

Ten grams of Hordeum roots (obtained from the seeds grown on Petri dishes as described in 3.1.1.) were ground with quartz in a mortar. After centrifugation at $10.000 \mathrm{~g}$ for 20 minutes at low temperature, the supernatant, after dilution by addition of distilled water, was used for the test. In order to demonstrate the enzyme Ubbelohde's viscosimetric method was uscd. The viscosimeter has a flow time of 14,1 seconds for water at $40^{\circ} \mathrm{C}$. Carboxymethylcellulose (AKU-CMC W 515) was used as substrate. For the tests $2,5 \mathrm{ml}$ of a $0,5 \mathrm{M}$ citrate buffer $(\mathrm{pH} 5.0), 5 \mathrm{ml}$ root extract and $7,5 \mathrm{ml}$ of a $1 \% \mathrm{CMC}$ solution were mixed. The test was carried out at $40^{\circ} \mathrm{C}$. The same mixture was used as control, the citrate buffer being re-

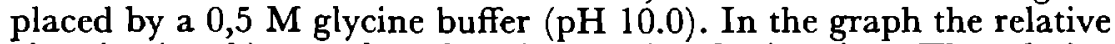
viscosity ( $\eta$ rel.) was plotted against the incubation time. The relative viscosity was found by dividing the flow time $(t)$ of the above mixture by the flowtime $\left(t_{0}\right)$ of the solvent, which, in this case, consisted of the root extract plus the buffer in question plus $7,5 \mathrm{ml}$ distilled water.

\subsubsection{Chitinase test}

In order to demonstrate a chitinolytic enzyme we used the method of East et al., modified according to Pugh, Leaback and Walker (1957). The substrate used was phenyl $\mathrm{N}$-acetyl- $\beta$-D-glucosaminide. The amount of phenol liberated by the enzyme was demonstrated in a Kipp colorimeter at $660 \mathrm{~m} \mu$, using the Folin-Ciocalteu reagent (HAIS and MAČEK 1958). Using appropriate dilutions of a pure phenol suspension, we established a linear relationship between the apparent extinction and phenol concentration. The phenol content of incubation mixtures could thus be calculated.

The extract for enzymatic investigation was obtaincd by grinding zygotes and mycelium with quartz in citrate buffer $0.1 \mathrm{M}, \mathrm{pH} 4.8$. After remaining at room temperature for some time, the homogenate was centrifuged and the supernatant was either tested immediately or further purified with acetone and tested afterwards. For the tests $1 \mathrm{ml}$ of the extract together with $2.9 \mathrm{mg}$ phenyl $\mathrm{N}$-acetyl- $\beta$-Dglucosaminide and $9 \mathrm{ml}$ citrate buffer $0.05 \mathrm{M}, \mathrm{pH} 4.8$ was incubated at $38^{\circ} \mathrm{C}$. After certain intervals $1 \mathrm{ml}$ was mixed with $2 \mathrm{ml}$ FolinCiocalteu (diluted one to three), as a result of which the reaction is stopped. Proteins were centrifuged down, and $2 \mathrm{ml}$ of the supernatant were mixed with $3 \mathrm{ml} \mathrm{Na} \mathrm{CO}_{3}(12 \% \mathrm{w} / \mathrm{v})$. Colour was developed by incubation at $38^{\circ} \mathrm{C}$ for $20 \mathrm{~min}$. Two controls were used in which substrate and extract were respectively omitted. 
Chapter 4

\section{FUSION BETWEEN VEGETATIVE CELLS}

\subsection{Vessel formation in the root of Hordeum vulgare}

\subsubsection{Introduction}

The development of vascular tissue in the root of Hordeum was studied in detail by Непмссн (1951), who published some observations on the central vessel, which is only present in the seminal roots. The term scminal roots was first used by MerRy (1941) and refers to the roots which originate from the root primordia in the embryo. The central vessel is regarded as constituting the late metaxylem. Heimsch noted that mature central vessels were only found in sections made at the bases of long main roots. He found the beginning of the differentiation of the central vessel close to the root apcx. Thus, in the tissue, the central vesscl starts differentiation first and ends last. The author finds that the level of differentiation depends on the growth rate of the roots. Rapidly elongating roots mature at a great distance from the apex, whereas slowly clongating roots mature closer to the apcx. Correlated with this is the branching of the roots. Rapidly elongating roots show little branching and only at a great distance from the apex, slowly elongating roots only branch close to the root apex. The same relation between growth rate and differentiation had already been observed by Esau (1948).

The same phenomenon was observed by us on Hordeum. Even under fairly constant conditions the level of maturation varied so markedly that of every root a length of $5 \mathrm{~cm}$ had to be examined in order to find the place of perforation. It was found at a level varying between 5 and $10 \mathrm{~cm}$ from the root apex. There were also differences in maturation level among the five to seven seminal roots of one sced. Heimsch (1951) also saw mature central vessels, but he was not able to determine the distance to the root apex.

\subsubsection{Situation in the cells of the central vessel before differentiation}

The cells of the central vessel develop directly from the stelar initial (fig. 1). They may then divide, once and possibly twice. This may be concluded from the division figures of the nuclcus (fig. 2) and varying thickness of the end walls (fig. 3). The organelles that occur in these cells do not differ from those that are found in other meristematic cells. The nucleus with nuclear envelope in which porcs occur contains two nucleoli (figs. 2, 3, 4). Further it is possible to discern the plasma membrane, mitochondria, Golgi bodies consisting of cisternae with vesicles, endoplasmic reticulum (after $\mathrm{OsO} 4$ fixation to be seen as rough and smooth), ribosomes (visible after OsO4 fixation), small vacuoles and plastids (figs. 4, 5, 6). The plastids do not yet contain starch. The end walls are of a primary nature. They originate like other cell walls in a meristimatic tissue (FrEYWYssLing et al. 1964). 
The end walls provided with numerous plasmodesmata have a wave-like appearance after $\mathrm{OsO} 4$ fixation (fig. 3). After $\mathrm{KMnO} 4$ fixation this effect is less obvious, probably because of the swelling caused by $\mathrm{KMnO} 4$ (fig. 2). The lateral walls contain fewer plasmodesmata. End walls, in tissue fixed with $\mathrm{OsO}_{5}$, are homogeneously electron transparent (figs. 3, 6). After $\mathrm{KMnO} 4$ fixation a vaguely bounded electron dense line appears in the middle of the wall (figs. $2,5)$. From the initial cell upwards the cells increase in width, the greatest width being attained between approximately the tenth and fifteenth cells. Beyond this point there are no longer divisions and elongation begins. This is a continuous process. Starting from a length of about 20 micron at the beginning of the elongation the length of the cells of the central vessel at maturation may be $1,5 \mathrm{~mm}$. In this development the following stages might be distinguished, although in fact these stages overlap each other.

\subsubsection{Differentiation of the central vessel}

\subsubsection{The swelling of the end wall}

The thickening end wall remains electron transparent, after $\mathrm{OsO} 4$ fixation. The number of Golgi bodies remains more or less constant, but their activity increases, which appears from the large quantities of vesicles that occupy the edges of the cisternae and also occur freely in the protoplasm (fig. 7). Material fixed with $\mathrm{KMnO} 4$ offers a slightly different picturc. In the middle of the end wall the dark line can now be scen more clearly and is bounded by a lighter edge on both sides. This edge is not sharply bounded and merges into a wider area which occupies the rest of the end wall and is electron dense to some extent (fig. 8). This division into laycrs is not clearly distinguishable in all cases, but depends on whether the end wall is cut perpendicularly. After $\mathrm{KMnO} 4$ fixation the end wall sometimes shows semi-spherical protuberances, the contents of which are mostly electron transparent (fig. 8). The endoplasmic reticulum is very conspicuous now that the ribosomes are not stained. It is often seen to run parallel to the end wall (fig. 8). The endoplasmic reticulum anastomoses, forming clews (fig. 9).

The increase in thickness of the end wall consequently takes place in the first millimetre from the apex, after that the appearance of the end wall does not change in the electron microscope before the maturation of the vessel. In the plastids starch has now been formed (fig. 9).

\subsubsection{Vacuolisation}

In the meristematic cells small vacuoles are already present (figs. $3,4)$, which increase in number and size and fuse. This process is a gradual one, with the result that in the second or third millimetre from the apex only one central vacuole and a thin parietal protoplasm are found. 


\subsubsection{Formations of secondary thickenings on the lateral walls}

This process has not been studied in detail. However, it may be observed that the formation of secondary thickenings in the central vessel of Hordeum starts late and is of short duration. During this formation the protoplasm with all its organelles is still intact.

\subsubsection{Degeneration of protoplasm and nucleus}

When the formation of the secondary thickenings on the lateral walls is finished, changes take place in the protoplasm. The vacuole membrane is no longer present everywhere. Mitochondria lose their cristae and become spherical. Other organelles and membranes become spherical as well, so that a vesicular structure originates, between which fragments of cytoplasm are found. Along the lateral walls the protoplasm often remains visible for a long time between the secondary thickenings. In the end it disappcars there, too, just like the plasma membrane. Fragments of protoplasm and plasma membrane are seen against the end wall, even during its breakdown. The nucleus increases in size from the beginning of the differentiation. At first it is spherical, but it becomes more and more lobed. After the protoplasm has become parietal, the nucleus is always found in the middle of the cell, never in the neighbourhood of the end wall. The two nucleoli remain. The nuclear envelope remains intact for a long time and the nuclear plasm does not change markedly. The lobed nuclei remain visible up to the end of the differentiation of the central vessel.

\subsubsection{Breakdown of the end wall}

The level of the maturation of the central vessel varies strongly and among other factors, depends on prior treatment. In our material this level lies at an average of $7 \mathrm{~cm}$ from the root apex. The OsO4 fixed material shows some differentiation in the end wall (fig. 10). In the middle is a diffuse electron transparent layer, bounded on both sides by an elcctron dense area, which, in its turn, merges into the much thicker electron transparent part of the end wall. This differentiation was not visible immediately after the swelling of the end wall. At first no breakdown stages were found, though stages were seen in which the end wall was intact and others in which it had disappeared completely. On closer investigation it appeared that there were openings in the end wall, mostly on the edge, but occasionally also in the centre (figs. 11, 12, 13). A small fragment of the end wall is also seen occasionally in the centre with an opening on either side (fig. 14). It is remarkable that the position of these fragments is not always at right angles to the lateral walls, but may form a different angle with them (figs. 13, 14). The openings we saw are real, that is to say pieces in the wall are lacking. These stages are always preceded by complete end walls (fig. 10) and followed by 
absence of end walls (fig. 15). The surfaces of the fractures suggest a mechanical breakdown (figs. 11, 12, 14, 15). In serial sections openings are also seen to be localised, which means that in successive sections at one level some contain complete end walls, others end walls with openings and others no end walls. All these cases can be understood if we assume that a peripheral part of the end wall disappears either enzymatically or mechanically by expansion of the vessel. The whole of the thick central part may now come off, be carried along by the sap and be dissolved in it. The above process may be reconstructed by means of the data obtained. The drawings (fig. B) represent transverse and longitudinal sections through the central vessel. By means of the longitudinal sections on the left it is possible to reconstruct the transverse section of the end wall. Longitudinal sections may of

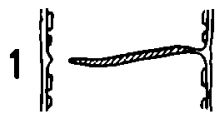

a<smiles>C=CCCCCCCCC</smiles>

2

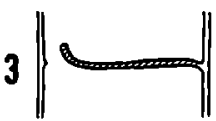

a

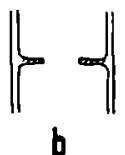

b
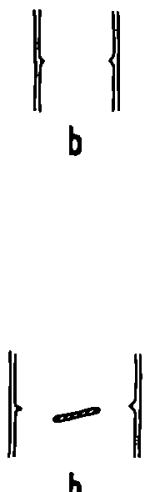

b
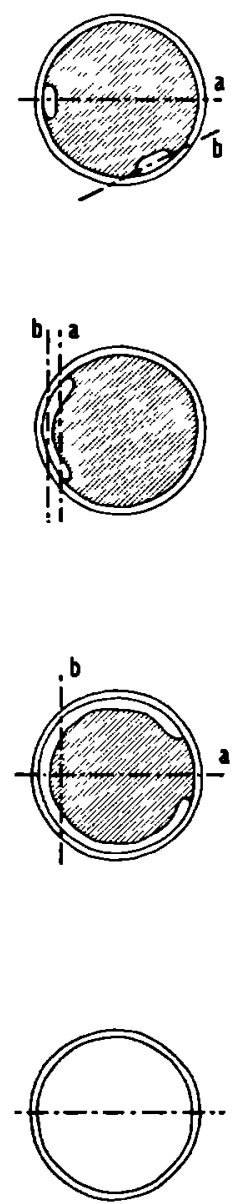

Fig. B. Scheme of the disappearance of the end wall in the central vessel of the root of Hordeum vulgare. (For explanation see text). 
course be found which do not contain openings. The situation represented in $1, \mathrm{~b}$ seldom occurs, which is understandable. A small change in the angle of this scction soon leads to a section of figure $B, 1$, a. If the opening in the end wall expands further, longitudinal sections may be expected of the types drawn in figure $B, 2$, a and $2, b$ and also of course end walls that are still intact. In $2, b$ the central vessel must of course be cut more tangentially than in figure 2 , a. In figure $B, 3$ we find roughly the same situation as in figure $B, 2$, the difference being that the fragments of the end walls form an angle with the lateral walls that is smaller than 90 degrees. These cases can only be accounted for if we assume that such a large part of the periphery of the end wall has come off that the remaining part of the wall hangs more or less loosely in the vessel. As a result of this the position of this part of the wall may change, the eventual position being determined by the embedding. The situation in figure $\mathrm{B}, 3$, $\mathrm{b}$ can never be explained of course by assuming that the central part of the end wall remains, there being nothing to keep it in its place. Eventually the remaining central part of the end wall will come off completely and we get the situation in figure B, 4. The situation described here applies to cases when the roots are fixed with OsO4. The end wall remains electron transparent to the end, apart from the slight differentiation that is visible after OsO4 fixation. Round the juncture of the end wall the secondary thickening is better developed than elsewhere. In a longitudinal section of the central vessel this secondary thickening is seen as a triangle (fig. 10). The edge of the end wall is clenched between two such thickenings. When openings occur the fractures are found where the secondary thickening stops or close by. The surface of the fracture is not quite smooth. Along the surface of the end wall some fragments of the protoplasm are still to be seen, often in the form of membranes or vesicles (fig. 12).

We find quite a different picture after $\mathrm{KMnO} 4$ fixation; a greater swelling of the end wall is to be seen, as a result of which its surface expands. We then get pictures as in figure 16 . The wall itself is fairly homogeneous and has a finc-grained structure, in which openings may originate (fig. 16). Details of such breakdown sites (fig. 17) show that the wall is broken up into more or less vesicular electron dense material. After $\mathrm{KMnO} 4$ fixation the wall may also split up into two parts, leaving a wide space between the two halves (fig. 18). These may fall into pieces and dissolve or come off at the edges (fig. 19).

In its primary state the end wall contains a skeleton of cellulose microfibrils, embedded in a matrix. The cellulose skeleton is visible when the tissue is treated with hydrogen peroxide and acetic acid. What is striking is the disappearance of the end walls from about $10 \mathrm{~mm}$ from the root apex after treatment with the above chemicals (fig. 20). The cellulose skeleton of the edge of the end wall, which does not swell, remains visible after treatment (fig. 21). However, an increasingly loose structure of the microfibrils in a centripetal direction may be observed. 


\subsubsection{Cellulase activity}

The root extract of Hordeum was tested on cellulase in a viscosimeter with CMC as a substrate. The optimum activity of cellulase lies at about $\mathrm{pH}$ 5.0. A buffer with $\mathrm{pH} 10.0$ was used as a control, since the activity of cellulase is minimal at this $\mathrm{pH}$. The relative viscosity $\eta$ rel. has been plotted on the ordinate. This is the flow time in seconds of the solution of extract plus buffer plus CMC, divided by the flow time in scconds of the solvent. On the abscissa the incubation time has been plotted in minutes. At pH 5.0 a clear decrease of the relative viscosity may be observed during the incubation time of one hour (fig. C). The activity of the extract depends strongly on the concen-

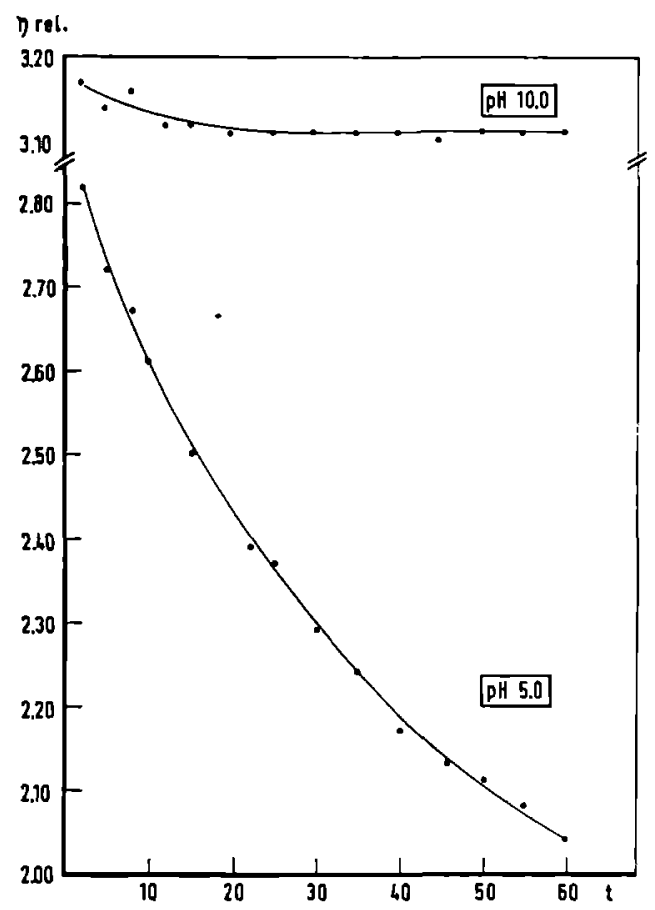

Fig. C. Cellulase activity in the root of Hordeum vulgare at $\mathrm{pH}$ 5.0. Control at $\mathrm{pH}$ 10.0. On the abscissa the incubation time $(t)$ in minutes, on the ordinate the relative viscosity, $\eta$ rel.

tration of the enzyme. The extract of 10 grams of roots is sufficient for a qualitative demonstration of the enzyme. At $\mathrm{pH} 10.0$ a slight enzyme activity may still be observed during the first few minutes in a slight decrease of $\eta$ rel. However, after that it remains constant during the rest of the test (fig. C). A few tests were also made with extract from germinated seeds of Hordeum. Using the same weight, we find a higher cellulase activity than in the root extract. 


\subsubsection{Discussion}

As to the thickening of the end wall before it is dissolved, our data agree with those of Esau et al. (1940, 1963) and Buvat (1964c). We think we have solved the problem of the sudden disappearance of the end wall, which has been observed but not investigated by most authors. The end wall is dissolved or mechanically pulled away along the edge where it is thinnest. As soon as this process is completed the rest of the end wall drops into the xylem vessel and may be further dissolved there. This solution process has not been observed but has been assumed. Esau (1936) has observed the same pictures but calls them artefacts. However, in our investigation these stages occur exclusively where the differentiation of the central vessel is almost complete. These end walls are exposed to the same artefacts over a distance of several centimetres before this point. However, they were never found there. Since Esau (1936) does not show any other photographs from which a gradual disintegration of the end wall appears and since she states that breakdown stages were seldom seen, we assume that our explanation also holds good for the case described by her. FLACH (1924), too, is of the opinion that the disintegration process must proceed rapidly, since stages of it were seldom observed. PRIEstley et al. (1935) state that the disappearance of the end wall must be a short process, since an intermediate stage was never seen by them. In our opinion they wrongly conclude from this that by rapid contraction the end wall forms a rim against the lateral wall. How are we to account for the totally different picture after $\mathrm{KMnO} 4$ fixation? $\mathrm{KMnO} 4$ is known to cause swelling e.g. Bersborn and MeNKe (1964). KMnO4 is further known to possess a strong oxidizing effect. We must assume that something happens in the end wall during the thickening process and after. The very effect of $\mathrm{KMnO} 4$ fixation points to this: the end wall at the beginning of the differentiation is stained in a way that is different from that of the maturation stage. In these last stages substances oxidized by $\mathrm{KMnO} 4$ prove to be present in much larger quantities than at first. Moreover the substances that are responsible for the swelling have greatly increased, which may be gathered from the shape of the end wall. The following hypothesis might be made. During the thickening process of the end wall substances from the protoplasm are incorporated into it. These substances may come from vesicles pinched off from the Golgi bodies and may be enzymatic in nature. By the incorporation of these substances the disintegration process is probably started inside and continues later, when the wall has come off. Certainly the living protoplasm plays no part in the dissolution process of the end wall. This was also found by F LACH (1924), who writes that in a later stage of differentiation the end wall also swells in the presence of diluted acids and that it splits up into two lamellae. This is the same effect as we found after $\mathrm{KMnO} 4$ fixation. He assumes that the end wall at first consists of hemicellulose, which is later replaced by pectin. According to Flach cellulose is absent. 
He thinks, too, that the resorption of the wall is caused by enzymes. These enzymes are assumed to be formed or stimulated by the degenerating protoplasm. It is impossible to tell with certainty how the thickening of the end wall is caused. However, a large number of Golgi bodies are found which contain vesicles, and protuberances of about the same size are often seen on the end walls. Buvat (1964c), also, assumes that substances in the Golgi vesicles are carried to the walls and incorporated into them, but he thinks that this is not simply a process of imbibition, but that it is controlled by the protoplasm. We, too, are of the opinion that Golgi bodies may be assumed to have a function in this process. What is transported in these vesicles is unknown. We think that there is a possibility that in this way enzymes are carried to the cell wall by the living protoplasm. This enzyme activity may be assumed from the increasing darkness of the end wall during the differentiation process and from its disintegration. The polysaccharides such as cellulose and hemicellulose that occur in this wall are apparently split up hydrolytically, as a result of which glucose, xylose, arabinose and mannose (among other substances) are formed. The aldehyde groups of these sugars may be oxidized by $\mathrm{KMnO}$, forming carbonic acids. The manganese liberated by the oxidation process makes the cell wall more electron dense. This strong oxidation caused by $\mathrm{KMnO} 4$ does not occur after OsO4 fixation. When fixed in this way the end walls remain electron transparent until they disappear, though the hydrolysis process must have made some progress. Figures 20 and 21 also point to disintegration in the end wall after thickening. Though the primary end wall contains cellulose, the thickened part of this wall disappears as a result of the above treatment long before the differentiation of the vessel is completed. The edges which do not thicken remain after this treatment. Thercfore it is not difficult to understand that, after coming off, the end walls are quickly dissolved. Besides it appcars from the cellulase test that the roots contain an enzyme which is capable of hydrolizing cellulose.

\subsection{Formation of laticifers in Achras sapota}

\subsubsection{Introduction}

In the work of KARLING (1929) a detailed study is made with the light microscope of the origin, shape and distribution of the laticifers in Achras sapota. As to the disappearance of the transverse walls of the laticifers Karling remarks that this process starts with the formation of an opening, usually at a pit connection, in the centre of a transverse wall. Further the author speaks of a gradual process. It is thought that the transverse walls do not always disappear completely. In such cases a ring-like ridge, extending into the lumen of the latex tube, remains. Karling is not sure whether these ridges ever disappear completely. 


\subsubsection{Observations with the electron microscope}

The laticifers in the apical meristem are easily seen because of their arrangement in rows in the longitudinal direction of the plant and because of the absence of a large central vacuole in the protoplasm. In the surrounding tissue, apart from the parenchyma cclls with large central vacuoles and chloroplasts, other cells occur, which also form rows in a longitudinal direction and after $\mathrm{KMnO} 4$ or $\mathrm{OsO} 4$ fixation, contain a dark matcrial, which is situated in the vacuoles. It consists of fine-grained electron dense material whose composition and possible function are unknown. The transverse walls of the laticifers are generally somewhat thinner than the lateral walls and the walls of the surrounding parenchyma cells (fig. 22). The middle lamella is occasionally visible, especially in the neighbourhood of the lateral walls. Plasmodesmata occur in the transverse wall but are not numerous. The protoplasm is surrounded by a plasma membrane. In the protoplasm of the cells which already show differentiation, apart from the usual organelles such as nucleus and mitochondria, other organelles occur, which, after $\mathrm{KMnO} 4$ fixation, are triangular and electron transparent. They are usually found in groups, surrounded by a membrane (figs. 22, 25). We also find organelles that are globular and electron dense, often showing an electron transparent part in the centre (figs. 22, 24). These organelles strongly resemble those that are later found in the laticifer, constituting the main part of the latex (fig. 23). The transverse wall breaks open around the centre and becomes gradually thinner towards the opening. The edge of the opening is curved (fig. 22), probably as a result of the flowing out of the latex in the direction of the cuttingplane. It is also possible that the walls which were not yet open, but showed a thin part in the centre, were opened mechanically in consequence of the reduction of pressure. On either side of the transverse wall, especially where breakdown takes place, electron dense bodies are found (figs. 24, 25). They occur between plasma membrane and ccll wall (figs. 26, 27). Near the open part of the transverse wall these dark particles merge (fig. 26). They are situated close to the cell wall and sometimes partly penetrate it. During this breakdown the organclles in the laticifers are still intact. The breakdown of the transverse wall now extends towards the periphery. Stages of complete breakdown of the walls are seldom observed. Also where the laticifers contain latex only, peripheral ridges of the transverse wall may still occur. The organelles of the protoplasm degenerate and only the electron dense organelles which constitute the latex remain (fig. 23). During the differentiation the cclls still increase in length. So cell wall growth still takes place along the lateral walls.

\subsubsection{Discussion}

The disappearance of the transverse walls usually starts in the centre with the formation of an opening. The breakdown process then proceeds in centrifugal direction, though it is not certain whether 
all transverse walls really disappear entirely. The electron dense bodies, found bctween plasma membrane and transverse wall after $\mathrm{KMnO} 4$ fixation, probably play a part in dissolving the cell wall, especially since they are frequently found where the wall thins down. It is not clear if they originate locally: they may be formed in the protoplasm and be deposited through the plasma membrane.

\section{Chapter 5}

\section{FUSION BETWEEN GENERATIVE GELLS}

\subsection{Zygote formation in Phycomyces blakesleeanus}

\subsubsection{Introduction}

After the hyphae of $(+)$ and (-) strains have touched, the ends swell. During their further growth the cclls spiral round each other and eventually form a loop, the ends of the cells remaining in contact. We now speak of the progametangia stage. The apices of these progametangia are separated from the rest by the formation of a new wall and are then called gametangia. They contain a multi-nuclear parietal protoplasm and a central vacuole. The wall between these two gametangia is broken down, so that the zygote can be formed.

We shall describe the protoplasmic components which do not change during the differentiation as well as the cell wall between the two gametangia, the fusion wall, which disappears during zygote formation.

\subsubsection{Protoplasm and cell wall before the fusion process}

The progametangia contain a large number of nuclei with a diameter of about 1 micron. These nuclei are surrounded by a nuclear envelope containing pores visible after $\mathrm{KMnO} 4$ fixation (fig. 28). After $\mathrm{OsO} 4$ fixation the nuclcolus is also visible. The nuclei are paired, the nucleoli usually facing each other. The paired nuclei are often flattened. Mitochondria occur in large numbers in the protoplasm.

They are of the usual type with cristae or tubuli (fig. 30).

Apart from the large central vacuole the protoplasm contains several small vacuoles (fig. 29).

Lipids occur as globular electron dense bodies, visible after $\mathrm{OsO}_{4}$ fixation (fig. 29).

We also find electron dense bodies that are slightly smaller, surrounded partly or completely by one or more layers of particles that are stained very darkly by $\mathrm{OsO} 4$ and lead citrate (fig. 31). The diameter of these particles is about $70 \AA$. They seem to be arranged as in a crystal. This is seen particularly well when such organelles are cut tangentially (fig. 31). Small vesicles with a dark 
content are also found; they are surrounded by a unit membrane (fig. 32).

Membrane systems occur on a large scale in the protoplasm. They are easily visible, especially after $\mathrm{KMnO} 4$ fixation. They are often seen in stacks, in close contact with the nuclei (fig. 33). These membrane systems bear a strong resemblance to the Golgi bodies, but the vesicles at the edges are lacking. Separate membranes, too, occur frequently. Ribosomes are found in large numbers. It is not certain whether they occur in close contact with membranes. However, as is shown by figures 30,31 and 34, two rows of alternating ribosomes are occasionally seen. The plasma membrane forms the boundary between protoplasm and cell wall (fig. 34 ). The gametangia originate as a result of the formation of a new cell wall on either side of the fusion wall. This new cell wall does not, as in higher plants, start with the formation of a cell plate in the centre of a cell, but grows out of the existing progametangium wall in a centripetal direction.

The beginning of cell wall formation need not take place simultaneously on both sides of the fusion wall. Sometimes the cell wall of one gametangium is already complete, whilst on the other side only a beginning has been made. The new cell wall grows inwards, from the progametangia wall, pushing the parictal protoplasm into the large central vacuole.

Usually several lamellae grow out of the progametangia wall at several points. These fuse into one cell wall, the protoplasmic inclusions being apparently resorbed. While the new wall is being formed vesicles are seen on both sides. It is not known how these vesicles, whose contents are electron transparent, originate. As has already been remarked, no Golgi bodies were found in the protoplasm. In the newly-formed gametangia we find a parietal protoplasm and a central vacuole. All the organelles that occur in the progametangia are also found in the gametangia and in the young zygote.

The cell wall of Phycomyces consists of a skeleton of chitin microfibrils and a matrix, containing, among other substances, hemicellulose and pectin. In thin sections the cell wall is electron transparent after fixation with OsO4 or $\mathrm{KMnO} 4$. After coming into contact, the tops of the progametangia flatten against each other. These flattened parts continue growing, and eventually form the fusion wall. No boundary can be seen between the two parts of this wall (fig. 35). Nevertheless the two parts can easily be loosened both mechanically and chemically. The fibrils of the chitin skeleton are not interwoven, only the matrices have coalesced. The fusion wall is about twicc as thick as the walls of the gametangia. Before the fusion no changes are observable on the fusion wall. $\mathrm{KMnO} 4$ and $\mathrm{OsO} 4$ fixation present the same picture.

\subsubsection{Breakdown of the fusion wall}

The fushion wall, which has so far been uniformly thick, begins to show thinner areas, where openings are formed in the end (fig. 32). 
This may happen during the last stage of the gametangia formation. The first perforation usually occurs in the centre of the fusion wall, but this is not always the case. Openings may be formed in different areas simultaneously. In thin sections parts of the wall are then seen as islets in the cytoplasm (figs. 28, 29). It is also possible to explain such islets by assuming that the edge of the remaining part of the fusion wall is lobed. The islets are then sections through the lobes. The edges of these islets may have all kinds of shapes, they usually thin down gradually (fig. 36). Openings may also sometimes be seen inside the fusion wall (fig. 37). These appear to be connected with the cytoplasm. The plasma membrane, which remains attached to the fusion wall during the dissolution process, also enters the openings inside the wall, just like the cytoplasm. After $\mathrm{KMnO} 4$ fixation we see more membrane systems and small vesicles around the breakdown areas of the fusion wall than along the part of the fusion wall which is still intact, or along other cell walls (figs. 28, 33, 36).

After $\mathrm{OsO} 4$ fixation this accumulation of membranes is not so clearly visible, but this is probably due to the large number of ribosomes. Membranes are present, however (fig. 30). During the fusion stage we see again the same organelles that were present during the previous stages of zygote formation. When the fusion wall is dissolved, the protoplasts of the two gametangia come into contact and plasma fusion takes place. During this process no changes are observed with the electron microscope. Further breakdown of the fusion wall eventually leads to one cell with a large central vacuole and a parietal protoplasm.

\subsubsection{Chitinase activity}

Since the cell walls of Phycomyces contain a chitin skeleton, an attempt was made to demonstrate a chitinolytic enzyme in the extract. First the pH optimum of this enzyme was determined, which was about $\mathrm{pH} 5,0$. As graph (fig. D) shows, an activity of the enzyme may be observed in the zygote extract. The substrate Phenyl $\mathrm{N}$-acetyl- $\beta$-D-glucosaminide is broken down and the quantity of liberated phenol increases with time (fig. D, 1). The control containing only extract and buffer also gives a positive reaction, especially when it is not further purified. In this case, however, the extinction does not increase with time. Also the control containing only substrate and buffer remains constant during the test. In the mycelium extract a chitinolytic activity is found as well (fig. D, 2). The enzyme found in the zygote makes the enzymatic brcakdown of the chitin in the fusion wall plausible.

\subsubsection{Discussion}

The protoplasmic organelles of the gametangia and of the young zygote of Phycomyces generally resemble those of higher plants. The nuclei are paired, which has also been observed by other authors 

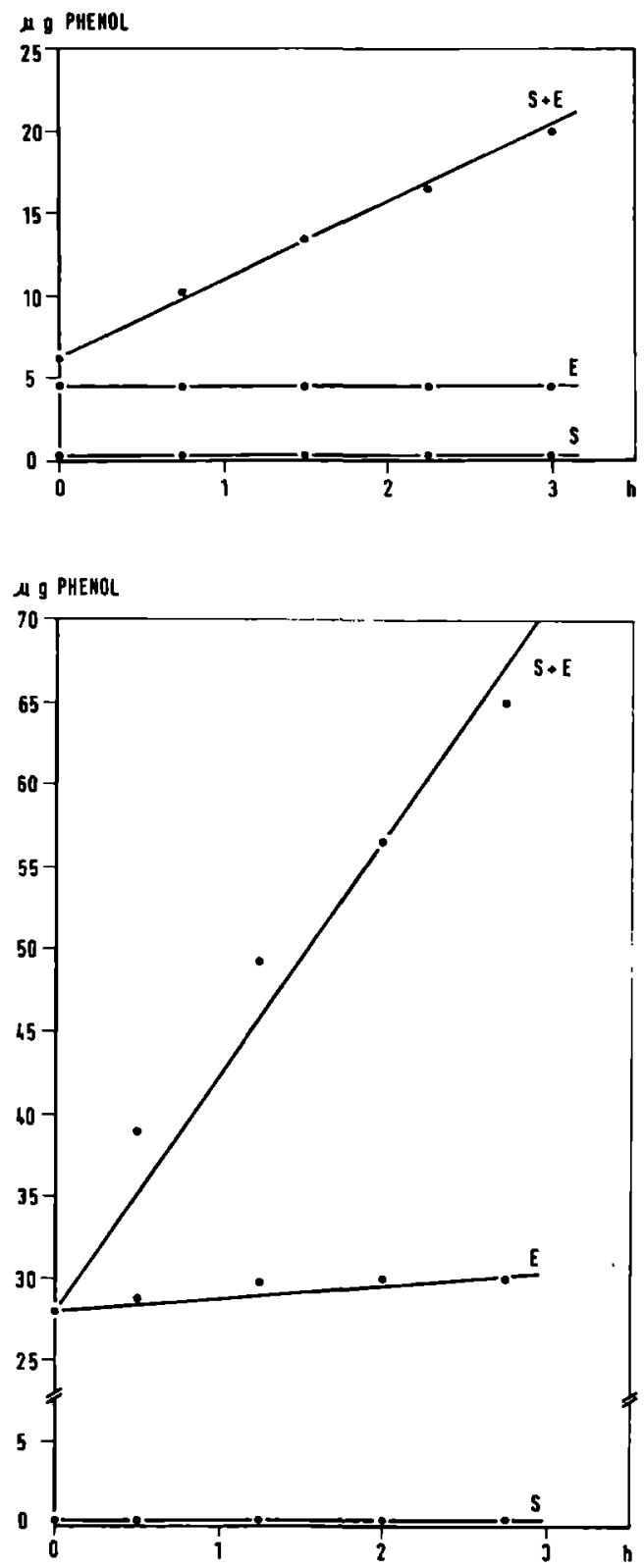

Fig. D. Chitinase activity in the mould Phycomyces blakesleeanus. 1. Activity of the enzyme in the zygote extract. 2. Activity of the enzyme in the mycelium extract. $\mathbf{s}=$ substrate; $\mathbf{E}=$ extract. On the abscissa the incubation time has been plotted in hours, on the ordinate the liberated phenol in $\mu \mathrm{g}$. 
(among others Gäumann 1949, Hawker et al. 1963). Mitochondria, plasma membranes and endoplasmic reticulum are completely comparable. Ribosomes occur very frequently in the gametangia, often in groups. Golgi bodies, however, are not present, at least not in the form in which they occur in higher plants. Membranes are found, which occur in stacks, but the characteristic protuberances at the edges were not observed. These membranes are often seen in connection with the nuclei, which is very clearly to be seen after $\mathrm{KMnO} 4$ fixation. Vesicles occur, especially along the growing cell walls that separate the gametangia from the zygophore. We might assume that these vesicles originate from those parts of the mould that are further away, i.e. from the hyphae. The way in which they originate, however, is unknown (SASSEN 1964b). They may probably be compared with the vesicles that take part in the cell wall growth of pollen tubes (SAssen 1964a). Here, too, the vesicles from the Golgi bodies are carried by the protoplasm to the top of the pollen tube, where they occur in large quantities and are involved in the cell wall growth. The vesicles around the growing wall in the zygote, too, are likely to have a transport function for the ground substances of the cell wall.

The electron dense particles that surround the unknown organelles in two rows may be compared with the reserve proteins in yolk granula of the Limnaea-egg, described by Elbers (1959). They are often arranged there like molecules in a crystal. The diameter of $70 \AA$ also agrees with our valucs. The electron density of the particles is not affected by staining with lead citrate. It is not known whether there are reserve proteins in Phycomyces. Since they occur on the surface of organelles that are fairly electron dense and homogencous, they may pcrhaps be looked upon as a protective layer for this substance.

The fusion wall. Observations with the electron microscope and previous observations with the light microscope clearly show that the fusion wall is broken down completely, including the skeleton which consists of chitin. However, the question may be asked where and how the hydrolytic enzymes work and why they work locally. From the observation that the plasma membrane always remains in close contact with the thinning fusion wall or parts of it, it might be concluded that the hydrolytic enzymes have a certain relation with the plasma membrane. The cell wall is only dissolved on the surface, so the enzymes do not penetrate the fusion wall. If they did, electron density of the fusion wall would probably change. An enzyme which is capable of breaking down chitin occurs in the zygotes and mycelium of Phycomyces. It is not clear, however, why breakdown is confined to the fusion wall. The hydrolytic enzyme only works during the zygote formation and must thus occur in an inactive state. It might be activated by substances which diffuse from one gametangium into the other. In that case an activity in the neighbourhood of the fusion wall might be accounted for. The greater activity of the membrane systcms points to this.

A second hypothesis might be that the enzymes which synthetize 
the cell wall substances are identical with those that are involved in the breakdown process. Conditions which may cause this change from synthesis to hydrolysis must again be looked for in the diffusion of substances from one gametangium into the other.

Our hypothesis that the hydrolyzing enzyme as well as the synthetizing enzyme must be in close contact with the plasma membrane is supported by submicroscopic investigation, with which we can demonstrate that the plasma membrane always remains in close contact with the fusion wall in dissolution. Also when openings are visible inside the wall, thesc openings are covered with a plasma membrane, which is locally invaginated.

\subsection{Zygote formation in Hansenula wingei}

\subsubsection{Introduction}

When (+) and (-) strains of Hansenula wingei are mated, a strong agglutination occurs (WICKERHAM 1956). This agglutination is so strong that the cells cannot be separated mechanically. BROGK (1959) thinks that the agglutination is a process which may be compared with the antigen-antibody reaction. On the cell wall surface of one strain a specific protein is thought to occur and on that of the other a spccific carbohydrate. After the agglutination the conjugation process starts with the formation of a conjugation tube. It is formed by the growth of that part of the cell wall that is situated near the partner cell. The ccll wall between the two cells-the fusion wallis then dissolved. This process lasts for about 10 minutes and takes place a few hours after agglutination. BROCK (1961) finds that a new enzyme is synthetized during the first part of the conjugation process. This enzyme is isolated and proves to be capable of breaking down substances in yeast cell walls (BROcK 1964). When seen in the electron microscopc the cell walls of yeasts consist of two layers (Northcote 1954, Mundkur 1960). The outer layer is supposed to contain chicfly mannan and chitin, the inner layer containing chicfly glucan.

\subsubsection{Structure of the cell wall and protoplasm of Hansenula wingei}

The cell wall consists of two layers (fig. 38), the inner layer being approximately thrce times as thick as the outer, which is more electron dense. On the surface of the cell wall there is a loose-woven, fairly electron dense structure with a variable thickness. It is locally absent and hence cannot be looked upon as a part of the cell wall itself.

After treatment of the cell wall with hydrogen peroxide and acetic acid a skeleton remains consisting of microfibrils, probably consisting of chitin. The plasma membrane surrounds the protoplasm and is undulating (fig. 38). We also find endoplasmic reticulum, mitochondria, vacuoles and nucleus (figs. 38, 42).

During bud-formation a new wall part is formed between the old and the new cell, which closes like a diaphragm, emerging from the 
inner layer of the mother cell wall (fig. 38). The cells treated with hydrogen peroxide and acetic acid show that the microfibrils of these so-called bud scars are orientated concentrically.

\subsubsection{The cell fusion process}

After agglutination the cells of the $(+)$ and $(-)$ strains start forming conjugation tubes. The cells grow narrower and longer and where they touch each other they are flattened (fig. 39). The centre of the fusion wall now thins down and an opening is formed, through which an exchange of protoplasma organclles is possible (fig. 40). The plasma membrane remains in close contact with the remaining part of the cell wall, which dissolves in a peripheral direction (figs. $40,41)$. Nuclcar fusion may occur, the nuclear membranes open and together they form the envelope of the fusion nucleus (figs. 42, 43). The last bits of the fusion wall disappear (fig. 43).

\subsubsection{Enzymatic aspects of the dissolution of the fusion wall in Hansenula}

Electron microscopically the disappearance of the fusion wall during the zygote formation of Hansenula is similar to that of the fusion wall in Phycomyces blakesleeanus. According to BROcK (1961, 1964) the enzyme involved in the dissolution of the cell wall is not synthetized until just before the cell fusion. The synthesis is supposed to take place after a diffusion of inducers from one cell into the other and vice versa. The amino acids in the cells, together with the inducers, are supposed to form the enzymes that are required for the dissolution process. Here, too, the question may be asked how the enzyme can work locally. It is possible that the inducers localise the enzyme formation. With the elcctron microscope no changes are observed in the protoplasm during the cell fusion. Here, too, the plasma membrane presumably plays an important part in the breakdown of the fusion wall, for this membrane remains in close contact with it, as in Phycomyces. From the work of ContI and Naylor (1960), who investigated zygote formation in Schizosaccharomyces octosporus with the electron microscope, the same conclusion may be drawn in regard to the dissolution of the fusion wall.

We seem to have established that the way in which the fusion wall of Hansenula dissolves is analogous to the dissolution of the fusion wall in Phycomyces.

\section{Chapter 6}

\section{GENERAL DISGLSSION}

From the four cases of cell fusion investigated here it has become clear that dissolution of that part of the wall which disappears during fusion is an enzymatic process. The skeleton, which in Hordeum and Achras consists of cellulose and in Phycomyces and Hansenula of chitin, 
as well as the matrix are broken down enzymatically. FREY-WYSSLING's hypothesis (1959) that during the cell fusion the matrix only is dissolved enzymatically but that the microfibrils are pushed aside mechanically, must be rejected as far as the cases investigated are concerned. Of the examples of cell fusion quoted in the literature, only two authors consider the possibility of a mechanical transportation of cell wall material. The first case was described by Priestley et al. (1935) on xylem vessels. Their arguments, however, are very unconvincing. Their main argument is that the breakdown of the end wall must proceed very rapidly, since they were not able to observe any stage in the breakdown process. Another author who assumes that the microfibrils are transported mechanically, and is of the opinion that this theory holds good for all ccll fusions, is FreyWyssling. This theory chiefly rests on the investigation of FREYWYSSLING and MüLLER (1957) concerning the origin of sieve pores in the sieve plates of Cucurbita. Objections to this conclusion have already been raised by Esau et al. (1962). In thin scctions they did not find a demonstrable force for a mechanical transportation of microfibrils in the cell wall. This also applies to the cell fusions investigated here. This theory is quite untenable in the case of fusion in xylem vessels, for here the protoplasm, the source of the mechanical force, disappears before the end wall. When surveying the cases of cell fusion quoted in the literature, we may conclude that the enzymatic breakdown of ccll walls during cell fusion is not confined to the four cases described in this study, but also holds good for other cases.

Electron microscopic information enables us to arrive at certain conclusions concerning the working of the cnzymes that are involved in the breakdown of cell walls during cell fusion. First of all there is a striking difference between the cell fusions that lead to the formation of xylem vesscls and those that lead to the formation of laticifers and zygotes.

In the xylem vesscls the end walls are dissolved after the degeneration of the protoplasm, so this protoplasm is not directly involved in the breakdown process. Another striking feature in xylem vessels is the considerable thickening of the end walls at the beginning of the differentiation. From these two data it may be concluded that the enzymes that are required for the breakdown are incorporated into the end wall during the thickening proccss. From that moment onwards a gradual breakdown of the cell wall components is possible and this process is no longer dependent on the protoplasm. This hypothesis is further supported by the totally different behaviour of the end wall after $\mathrm{KMnO} 4$ fixation. From this, too, we must conclude that the enzymes are active inside the end wall during the differentiation process. There is ample evidence in literature (e.g. FlaGH 1924, Duerden 1934, Priestley et al. 1935, Esau and Hewitt 1940 and ScotT et al. 1960) that the end wall disappears suddenly during the formation of the xylem vessels and that stages in the breakdown process do not occur very frequently. EsAu (1936) remarks that she has frequently seen certain stages in which the end walls have become tilted but 
is of the opinion that this is due to artefacts caused by cutting. These very stages were also frequently observed by us, but only at that level in the root at which differentiation was almost complete. We then realized that we are not concerned with artcfacts here, but with real stages in the dissolution of the end wall. If we assume that enzymes are active in the wall, the end wall will be weakest where it is thinnest, that is where it is attached to the lateral walls. A weak mechanical force may then cause the end wall to come off in its entirety.

This force might be the flow of sap in the completed part of the vessel. In this way a rapid disappearance of the end wall may be accounted for. The dissolution of the detached cell wall may subsequently be completed. The cell fusions in xylem vessels, where no plasma fusion takes place, may be contrasted with those in laticifers and zygotes, where the plasma fusion constitutes an important part of the cell fusion. The gradual and regular breakdown of the transverse wall or fusion wall in the latter is probably connected with this. The fusions in the laticifers of Achras occupy a kind of intermediate position. It is true that the dissolution of the transverse wall starts while the protoplasm is still alive, but the latex in the older laticifers can no longer be looked upon as a living protoplast. The degeneration of the protoplasm may also be the cause of the incomplete dissolution of some transverse walls.

It is not quite clear how the transverse walls in the laticifers dissolve. It is a gradual process, however. The plasma membrane also remains in close contact with the wall during its dissolution. This plasma membrane may possibly have something to do with the breakdown, which may also be true of the dark particles that are situated between plasma membrane and cell wall. It is not known how the breakdown process is induced. We must assume that the protoplasts on both sides of the transverse walls are identical, since they are in contact via the plasmodesmata. The inducers must probably be looked for in the protoplasm itself, which undergoes a considerable change during differentiation. During the zygote formation of Phycomyces and Hansenula we see breakdown stages that are more or less identical. During the wholc of the breakdown process the plasma membrane remains in close contact with the fusion wall. The plasma membrane with its enzymes no doubt plays an important part in the breakdown process. It is not quite clear whether we are dealing with newly-formed enzymes, as Brock (1961) postulates for Hansenula, or with enzymes that were already present, which first synthetized the cell wall and now work in the opposite direction as a result of equilibrial changes.

Since we are concerned with fusions of cells of different sexcs, we may assume that substances which diffuse from one cell into the other and vice versa induce the breakdown process, either through production of new enzymes or through changing synthesis into breakdown. 


\section{SUMMARY}

During differentiation processes in plants in which cell fusions occur the cell walls that are involved in the cell fusions are broken down either completely or partly. This breakdown does not take place in the same way in all cases.

In the central vessel of the root of Hordeum vulgare a marked thickening of the end wall occurs at the beginning of differentiation. At maturation this thickened end wall comes off from the lateral wall of the vessel, in which the breakdown process is completed. The coming off is probably caused mechanically. The flow of sap in the mature vessel may have something to do with this. The protoplasm degenerates before the end wall is broken down and therefore cannot be responsible for this process. However, there are indications that the hydrolytic enzymes were already incorporated from the living protoplasm into the end wall during its thickening. One of these indications is the totally different picture of the end wall after KMnO4 fixation. Other evidence is the disappearance of the cellulose microfibrils at an early stage of the differentiation after treatment of the roots with acids.

In the other three cases of cell fusion that were investigated cell wall breakdown takes place while the protoplasm is still alive. What is striking here is the close contact between the plasma membrane and the cell wall in dissolution.

The breakdown process starts in the centre of the cell wall and gradually extends in a centrifugal direction. In Achras sapota not all transverse walls are dissolved completely. In Phycomyces blakesleeanus and Hansenula wingei the fusion wall disappears completely. We have reason to believe that the breakdown of the cell wall in the last three cases is caused by enzymes that are attached to the plasma membrane. The activation or formation of these enzymes in the case of the cell fusions that take place between gametes may be induced by substances derived from the partner cell. This might also account for the local activity of these enzymes.

\section{ACKNOWLEDGEMENTS}

The author is very much obliged to Miss Frieda Hutjes for skilful technical assistance and for typing the manuscript. He is also indebted to Drs. F. G. A. M. Aarts for translating the text into English and to Mr. J. Crawley for checking the Fnglish translation.

Part of this work has been supported by the Netherlands Organisation for the Advancement of Pure Research (Z.W.O.).

\section{REFERENCES}

Blakeslee, A. F. 1904. Proc. Am. Acad. Arts Sci. 40: 205.

Berzborn, R. und W. Menke. 1964. Z. Naturforsch. 19 b: 763.

Brock, T. D. 1959. J. Bacteriol. 78: 59.

1961. J. gen. Microbiol. 26: 487.

1964. J. Cell Biol. 23: 15A.

Brown, W. V. and SR. C. Johxson. 1962. Amer. J. Bot. 49: 110.

Buvat, R. 1964a. C.R. Acad. Sci. Paris 258: 5243.

1964b. C.R. Acad. Sci. Paris 258: 5511.

1964c. C.R. Acad. Sci. Paris 258: 6210.

Chardard, R. 1962. Rev. Cytol. Biol. Végét. 24: 1.

Cont, S. F. and H. B. NAYlor. 1960. J. Bacteriol. 79: 331.

Diers, L. 1963. Z. Naturforsch. 18 b: 562 .

DiPPEL, L. 1851. Verhandl. Bataafsch Genootsch. 12: 7.

Duerden, H. 1934. Ann. Bot. (Lond.) 48: 459.

Eames, A. J. and L. H. MacDaniels. 1925. An Introduction to Plant Anatomy, McGraw-Hill, New York and London.

Elbers, P. F. 1959. Over de beginoorzaak van het Li-effect in de morphogenese, Libertas N.V., Utrecht. 
EsAu, K. 1936. Hilgardia 10: 479.

1948. Hilgardia 18: 423.

V. I. Cheadle and E. B. Risley. 1962. Bot. Gaz. 123: 233.

and $\mathrm{T}$. 1963. Bot. Gaz. 124: 311.

Eschrich, W. 1963. Protoplasma 56: 718.

Flach, P. 1924. Sitzber. Akad. Wiss. Wien, Math.-Nat. Kl. Abt. 1. 133: 265.

Frey-Wyssling, A. 1959. Die pflanzliche Zellwand, Springer-Verlag, BerlinGottingen-Heidelberg.

— and H. R. Muller. 1957. J. Ultrastructure Res. 1: 38. Res. 10: 422.

Gäumann, E. 1949. Die Pilze, Birkhảuser, Basel.

GirbardT, M. 1962. Z. Naturforsch. 17 b: 49.

HaIs, I. M. und K. MAČEK. 1958. Handbuch der Papierchromatographie, VEB Gustav Fischer, Jena Band 1.

Heimsch, C. 1951. Am. J. Bot. 38: 523.

Hawker, L. E. and P. McV. Aвbott. 1963. J. gen. Microbiol. 30: 401.

Heslop-Harrison, J. 1964. In: H. F. Linskens (ed.): Pollen Physiology and Fertilization 39, North-Holland Publ. Co. Amsterdam.

JAHN, A. 1934. Z. Bot. 27: 193.

Karling, J. S. 1929. Am. J. Bot. 16: 803.

KoHLER, E. 1929. Planta 8: 140.

Kúster, E. 1956. Die Pflanzenzelle, VEB Gustav Fischer, Jena, 3, Aufl.

LAibach, F. 1918. Planta 5: 340.

Ling-Young. 1930. Rev. gén. bot. 42: 618.

Merry, J. 1941. Bull. Torrey bot. Club 68: 585.

MundkuR, B. 1960. Exper. Cell Res. 20: 28.

MeYer, A. 1902. Bot. Z, 60: 162.

Northcote, D. H. 1954. J. gen. Microbiol. 11: 8.

Plurjm, J. E. v. D. 1964. In: H. F. Linskens (ed.): Pollen Physiology and Fertilization 8, North-Holland Publ. Co. Amsterdam.

Priestley, J. H., L. I. Scott and M. E. Malins. 1935. Proc. Leeds Phil. Soc. $3: 42$.

Pugh, D., D. H. Leaback and P. G. Walker. 1957. Biochem. J. 65: 464.

ReYNolds, E. S. 1963. J. Cell Biol. 17: 208.

Sabatini, D. D., K. G. Bensch and R. J. Barnett. 1963. J. Cell Biol. 17 : 19.

Sassen, M. M. A. 1962. Proc. Kon. Nederl. Akad. Wet. (Amsterdam) Ser. C 65: 447. 1964a. Acta Bot. Neerl. 13: 175.

1964b. Electron Microscopy 1964 B, Publ. House Czech. Acad. Sci. Prague.

ScotT, D. H. 1882. Quart. J. Micr. Sci. 22: 136.

ScotT, F. M., V. Sjaholm and E. Bowler. 1960. Am. J. Bot. 47: 162.

Waterkeyn, L. 1962. La Cellule 62: 225.

Wickerham, L. J. 1956. C. rend. trav. lab. Carlsberg, Sér. Physiol. 26: 423.

\section{EXPLANATION OF FIGURES $1-43$}

Fig. 1. Avena sativa

Figs. 2-21. Hordeum vulgare

Figs. 22-27. Achras sapota

Figs. 28-37. Phycomyces blakesleeanus

Figs. 38-43. Hansenula wingei 


\section{KEY TO LABELING}

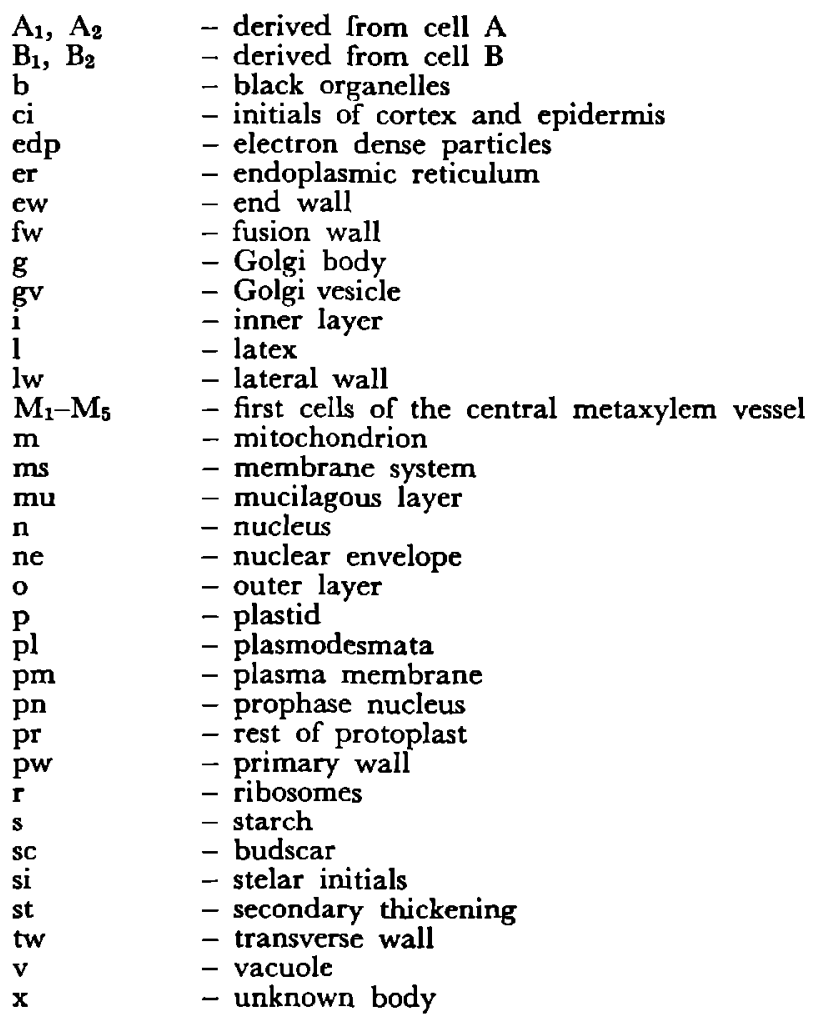




\section{LLGENIS}

Fig I Median longitudinal section of the root tip Fix glut ald | KMnO4

Fig 2 Lower part of the central vessel One nucleus is in prophase Fix glut ald KMnO4

Fig 3 Lower part of the central vessel Fix glut ald 0 OsO4

Fig 4 Cell from the lower part of the central vessel Fix glut ald KMnO4

Fig 5 Detall from the cell in the lower part of the central vessel Fix glut ald KMnO4

Fig 6 Detall from the same kınd of cell as in fig $5 \quad F_{1 X}$ glut ald $\mathrm{OsO4}$

Fig 7 Activity of the Golgi bodies in an early stage of differentiation Fix glut ald 1 KMnO4

Fig 8 Laycrs in the end wall during thickcning $F_{1 x}$ glut ald $\ulcorner$ KMnO4

Fig 9 Early stage of differentuation in a cell of the central vessel Vote the anastomosing endoplasmic reticulum and the starch in the plastids Fix glut ald KMnO4

Figs 10-15 Stages in breakdown of the end wall Fix glut ald OsO4

Fig 16 Swollen end wall after $\mathrm{KMnO} 4$ fixatıon In the centre the breakdown process started

Fig 17 Detall of the disintegratıng end wall after $\mathrm{KMnO} 4$ fixation

Гig 18 End wall divided into two parts after $\mathrm{KMnO} 4$ fixation

Fig 19 Both parts of the end wall are being detached from the lateral wall Fix glut ald

Fig 20 End wall has disappeared after treatment with hydrogen peroxide and acetic acid

$\mathrm{KMnO4}$

Fig 21 Detall from part of the end wall that does not disappear

Fig 22 Origin of openings in the transverse walls of a young ldicifer Fix glut ald - KMnO4

Fig 23 Mature laticifer contaınıng latex $\mathrm{F}_{1 \mathrm{x}}$ glut ald $\mathrm{OsO4}$

Fig 24 and fig 25 Detals, showing central opening in the transverse wall Fix glut ald KMnO4

Fig 26 Enlargement of a part of the transverse wall in dissolution Note the thinning down of the wall towards the opening and black orgdnelles between cell wall and plasma membrane

Fix glut ald । $\mathrm{KMnO4}$

Fig 27 Detail of black organellcs, showing their position between plasma membrane and ceil wall Fix glut ald - KMnO4

Fig 28 Part of the zygote with the remnants of the fusion uall Note the small piece of the fusion wall marked with an arrow Fix glut ald - KMnO4

Fig 29 Openings in the lusion wall of the zygote Fix glut ald OsO4

Fig 30 Place where the fusion wall is broken down Fix glut ald - OsO4

Fig 3I Part of the protoplasm showing bodies surrounded by electron dense particles The lower one is cut tangentially Fix glut ald OsO4

Fig 32 Breakdoun of the fusion wall $\mathrm{Fix}$ glut ald $\mathrm{OsO4}$

Fig 33 Remnant of the fusion wall in the protoplasm Note the activity of the endoplasmic retıculum around the rest of the lusion wall Fix glut ald I $\mathrm{KMnO}^{4}$

Fig 34 Part ol protoplast and fusion wall in the zygote Fix glut ald OsO4

Fig 35 Part of tuo gametangia on both sides of the fusion wall Fix glut ald $\vdash \mathrm{OsO4}$

Fig 36 Place where the fusion wall is broken down The end of the wall surrounded by endoplasmic reticulum Fix glut ald - KMnO4

Fig 37 Protoplasm in the fusion wall Fix glut ald, OsO4

Fig 38 Dividing cell The new wall -the future bud scar-is being formed, originating from the inner part of the mother cell Fix glut ald I $\mathrm{KMnO}_{4}$

Fig 39 Zygote formation Conjugation tube is already formed Fix glut ald | KMnO4

Fig 40 Central part of the fusion wall is dissolved Fix glut ald $\vdash$ KMnO4

Fig 4I Dissolution of the fusion wall is almost completed Fix glut ald $\mid \mathrm{KMnO} 4$

Fig 42 Fusion of the nuclel Fix glut ald | KMnO4

Fig 43 Cell fusion and nuclear fusion are completed Fix glul ald + KMnO4 


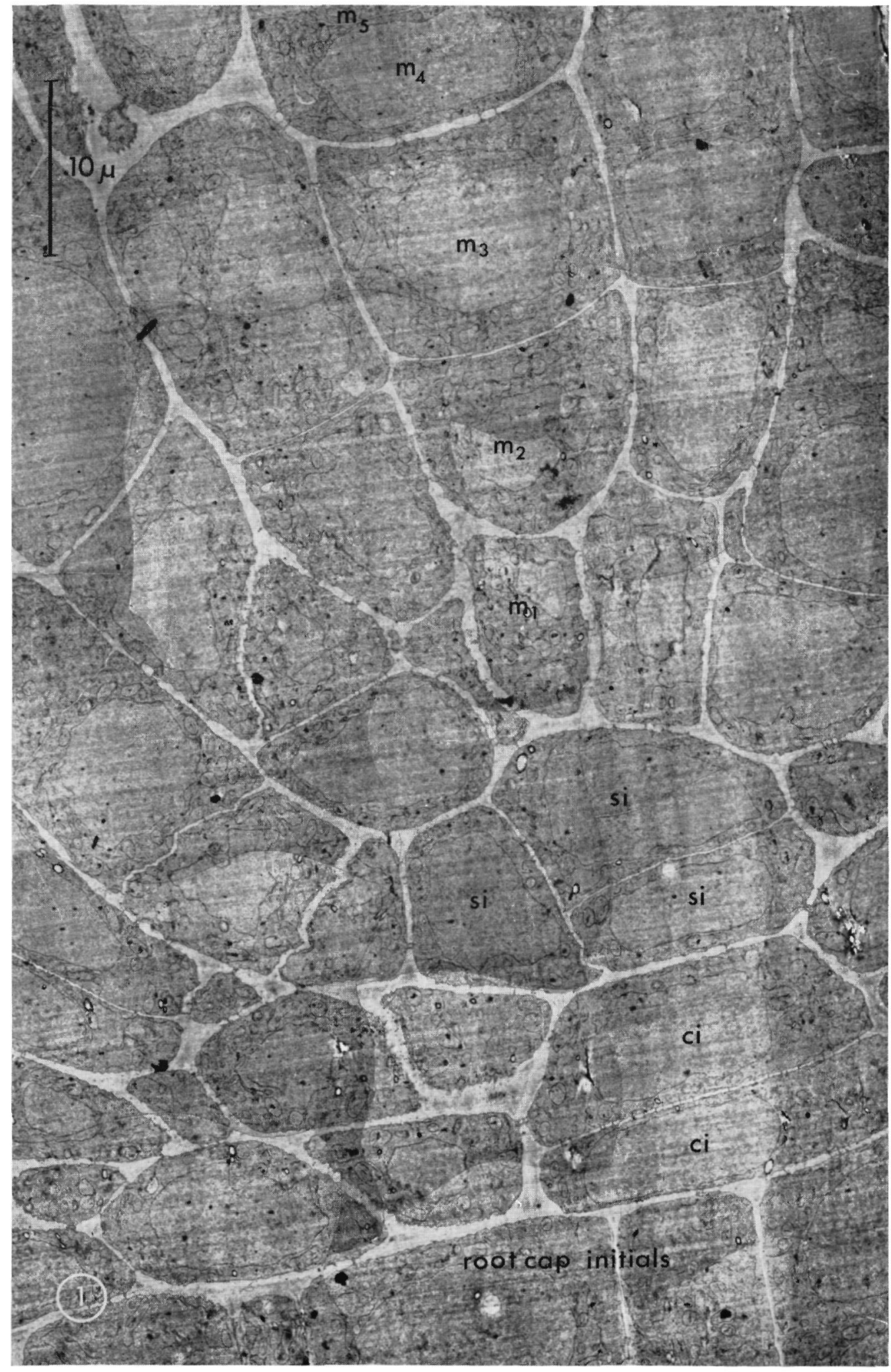




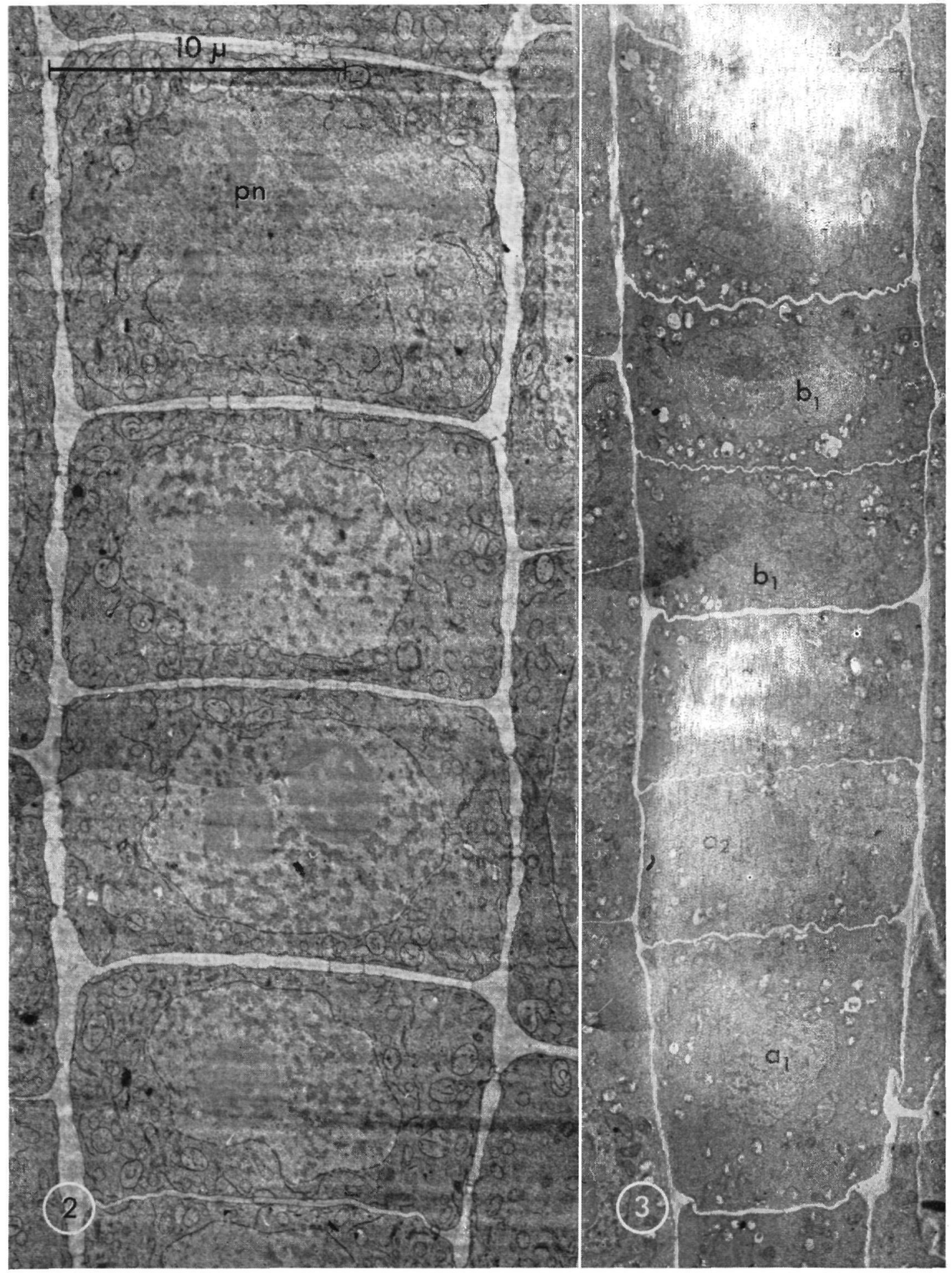




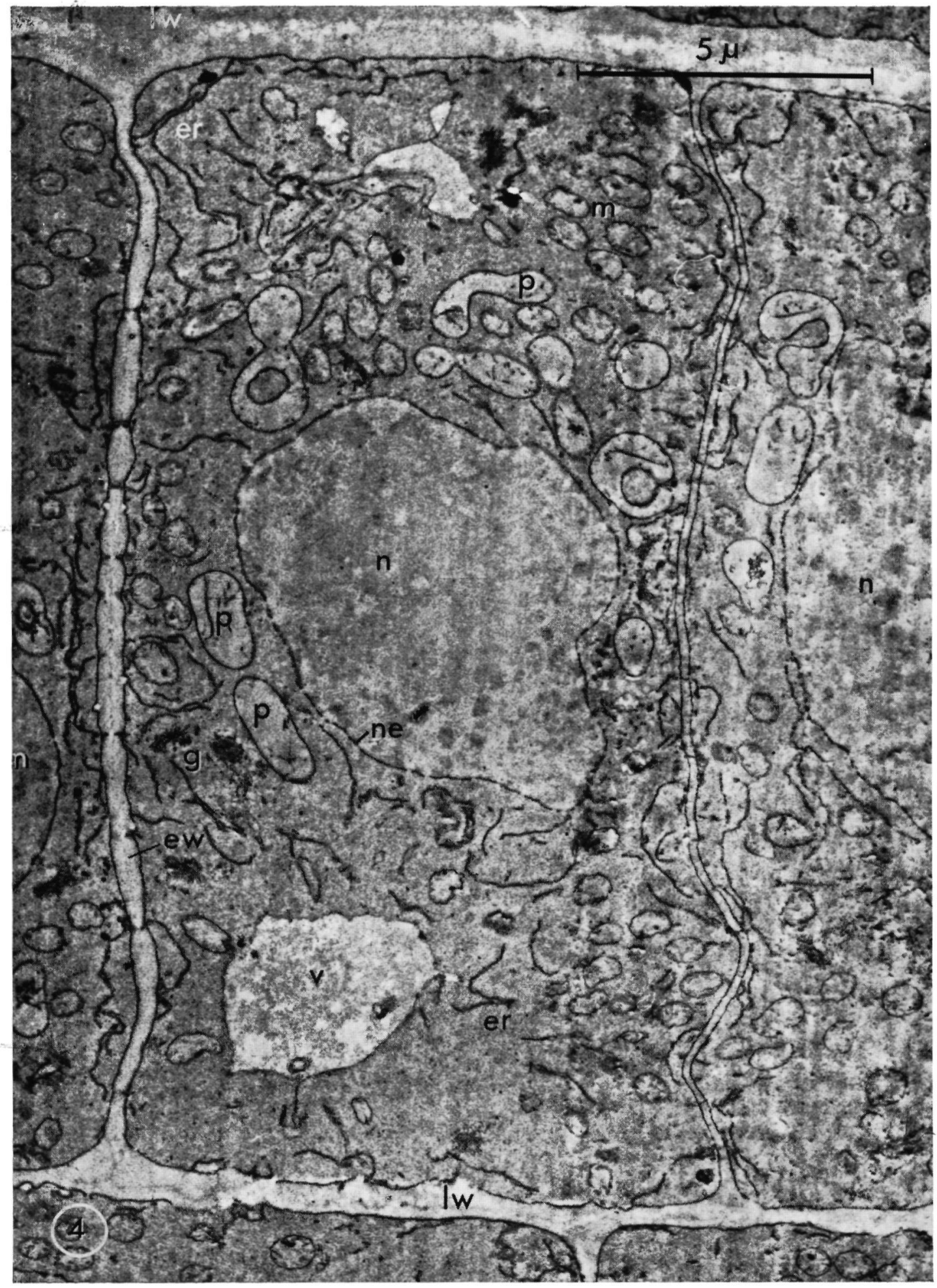



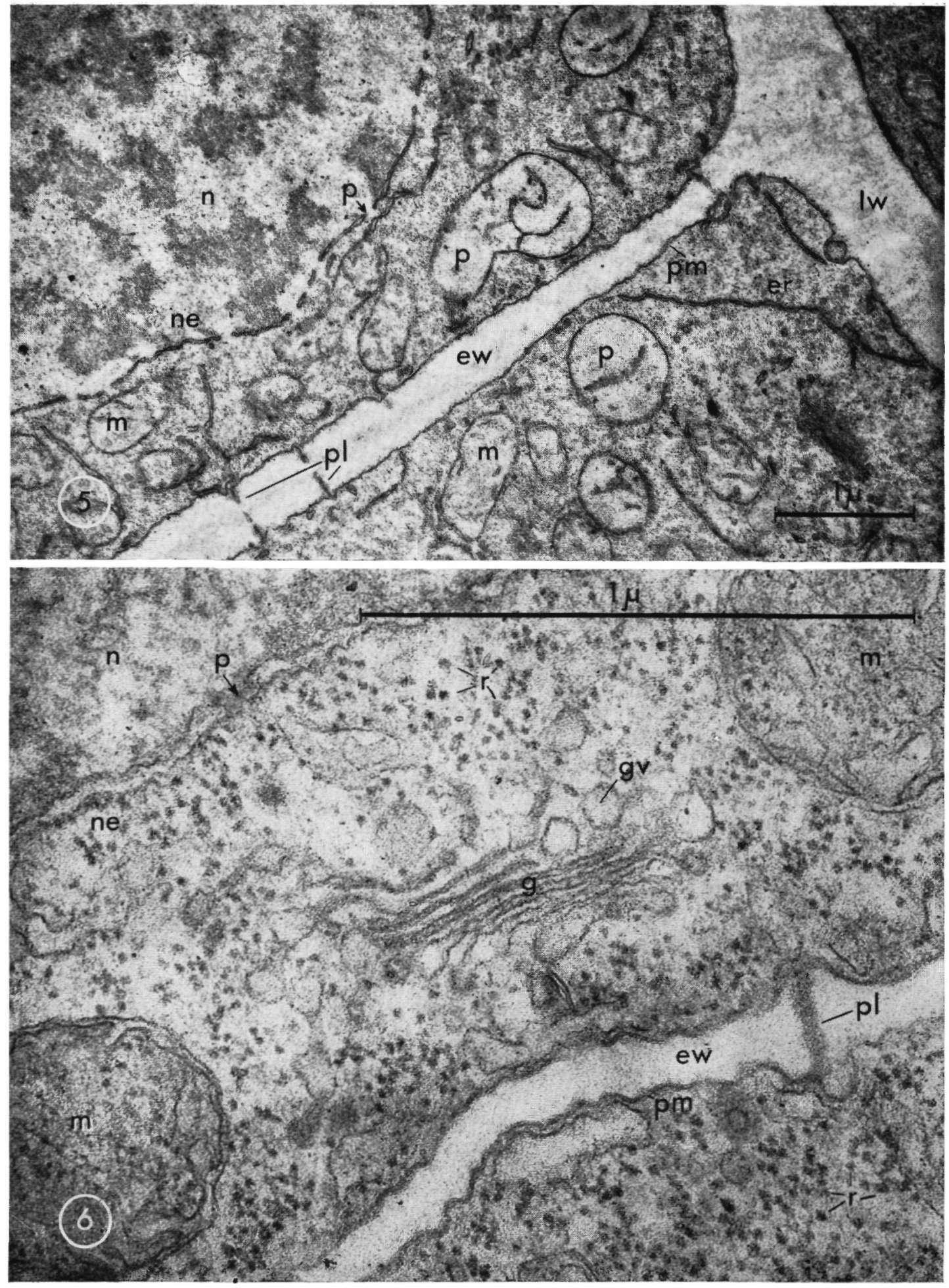


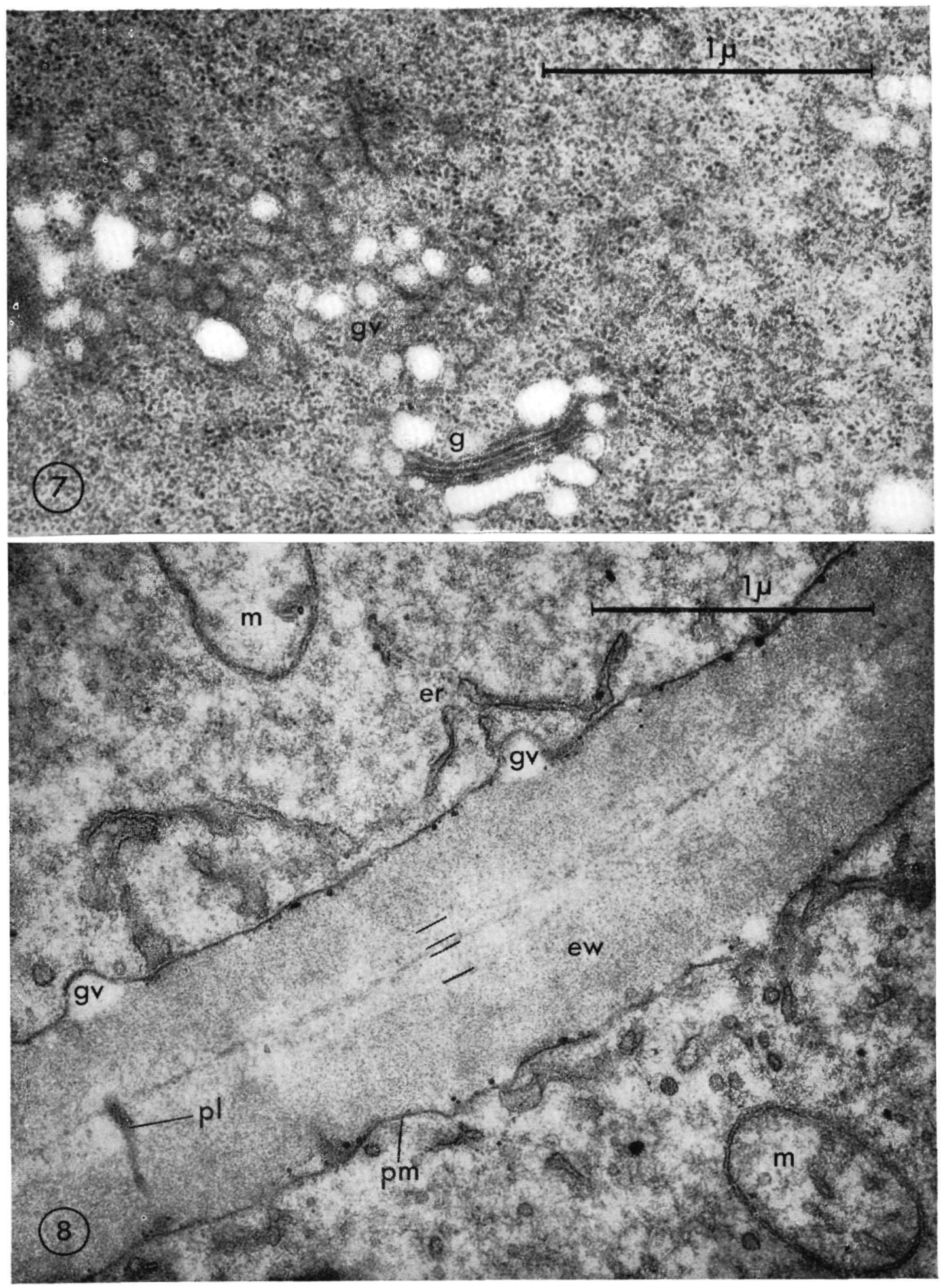




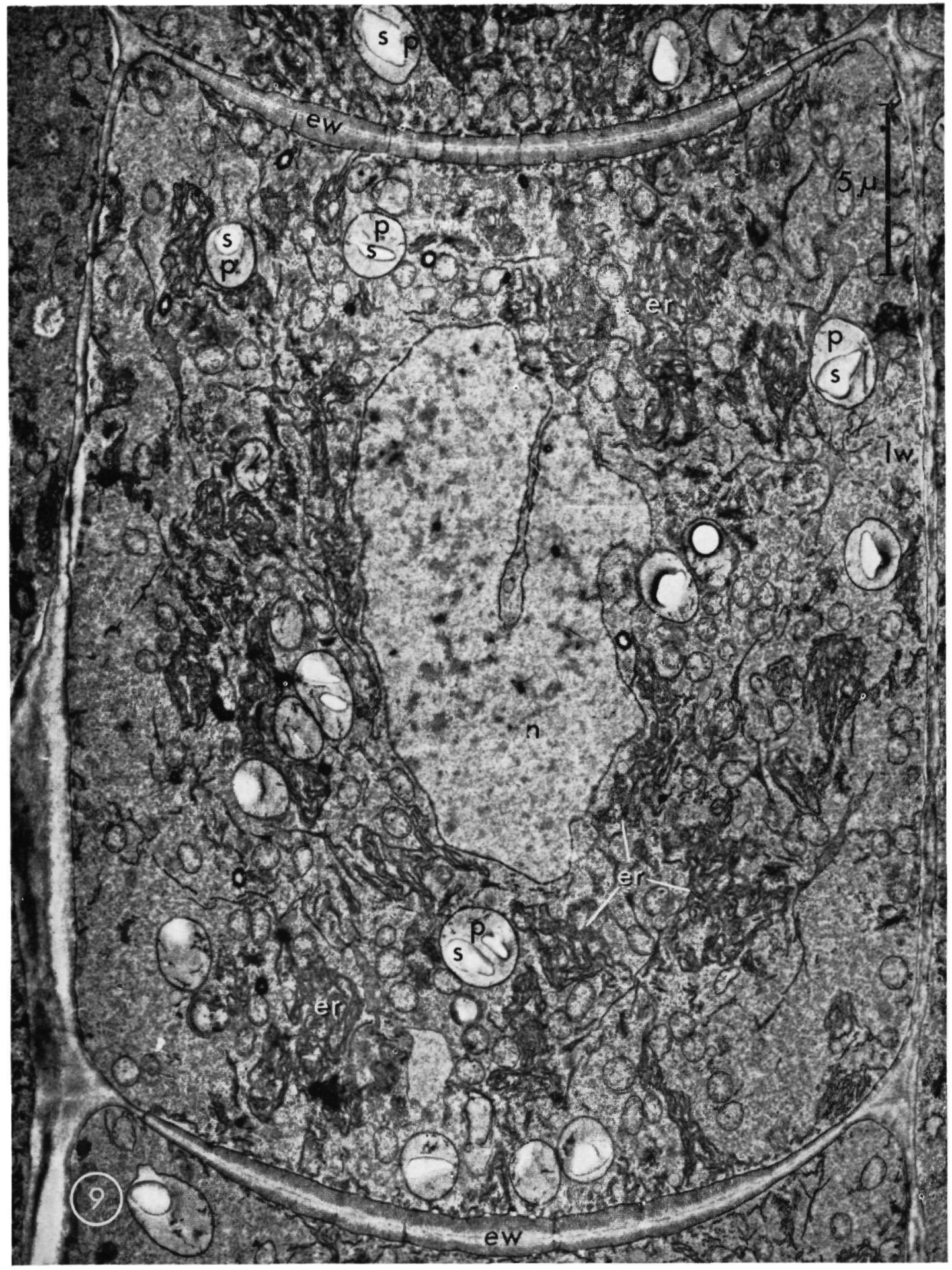




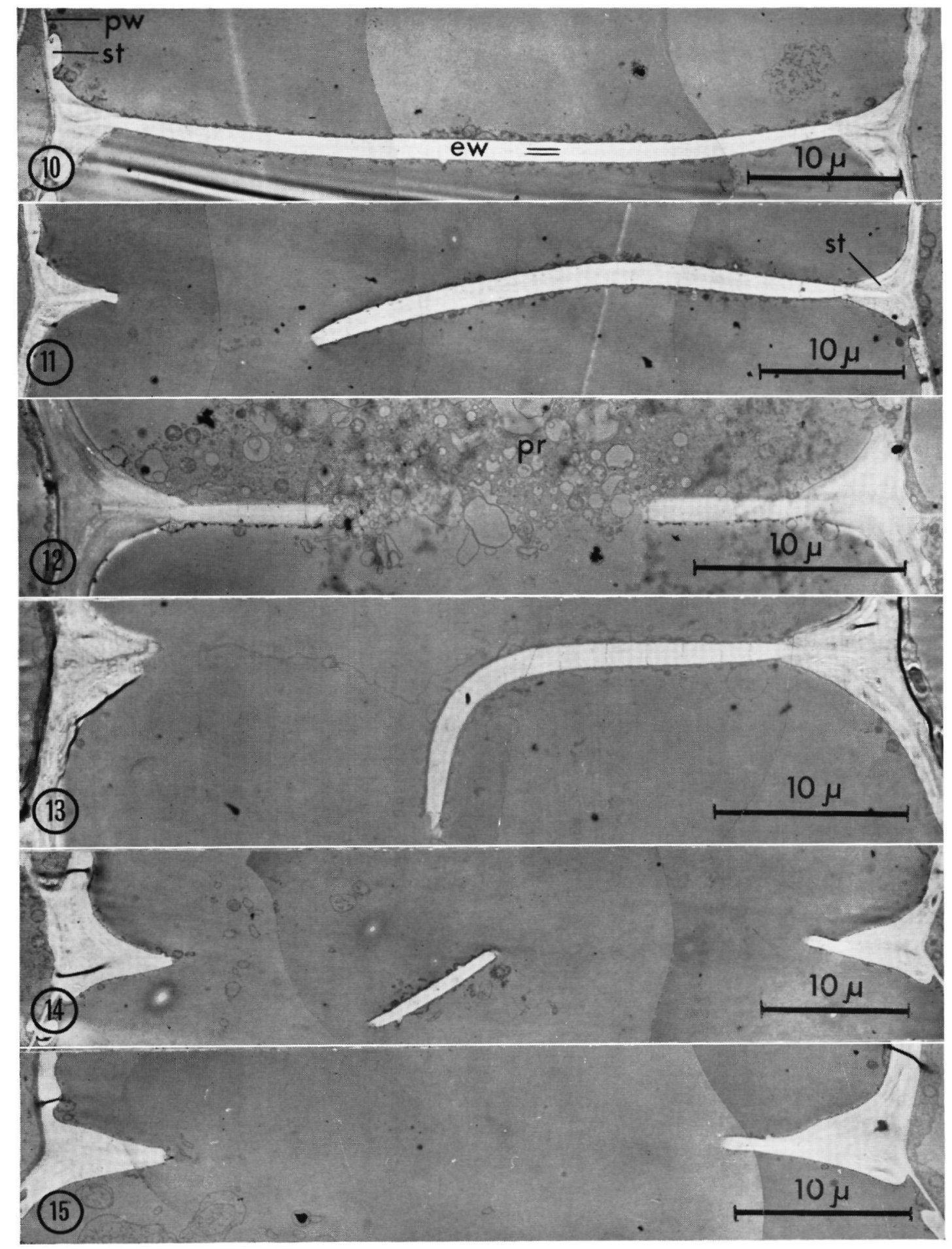




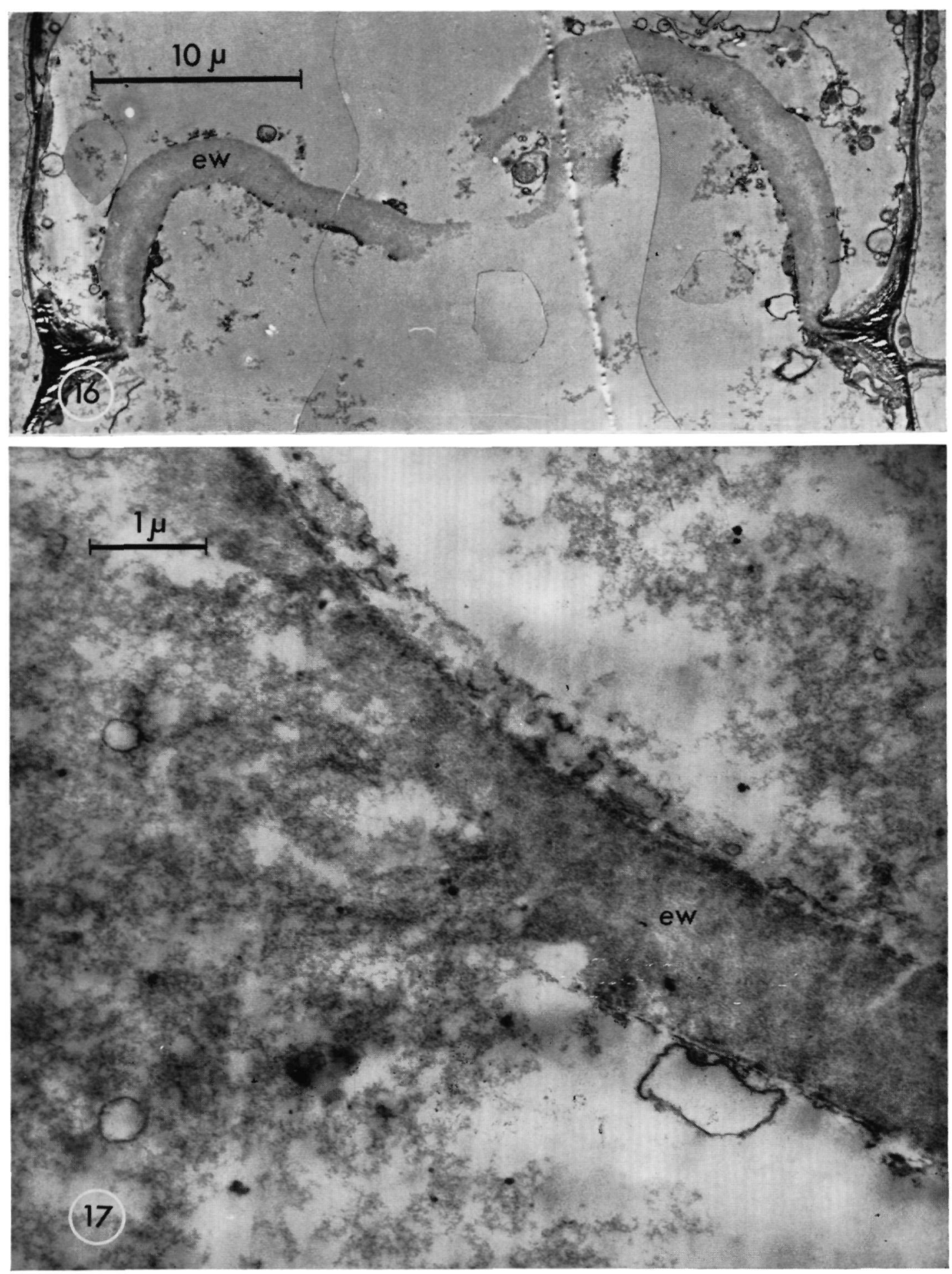



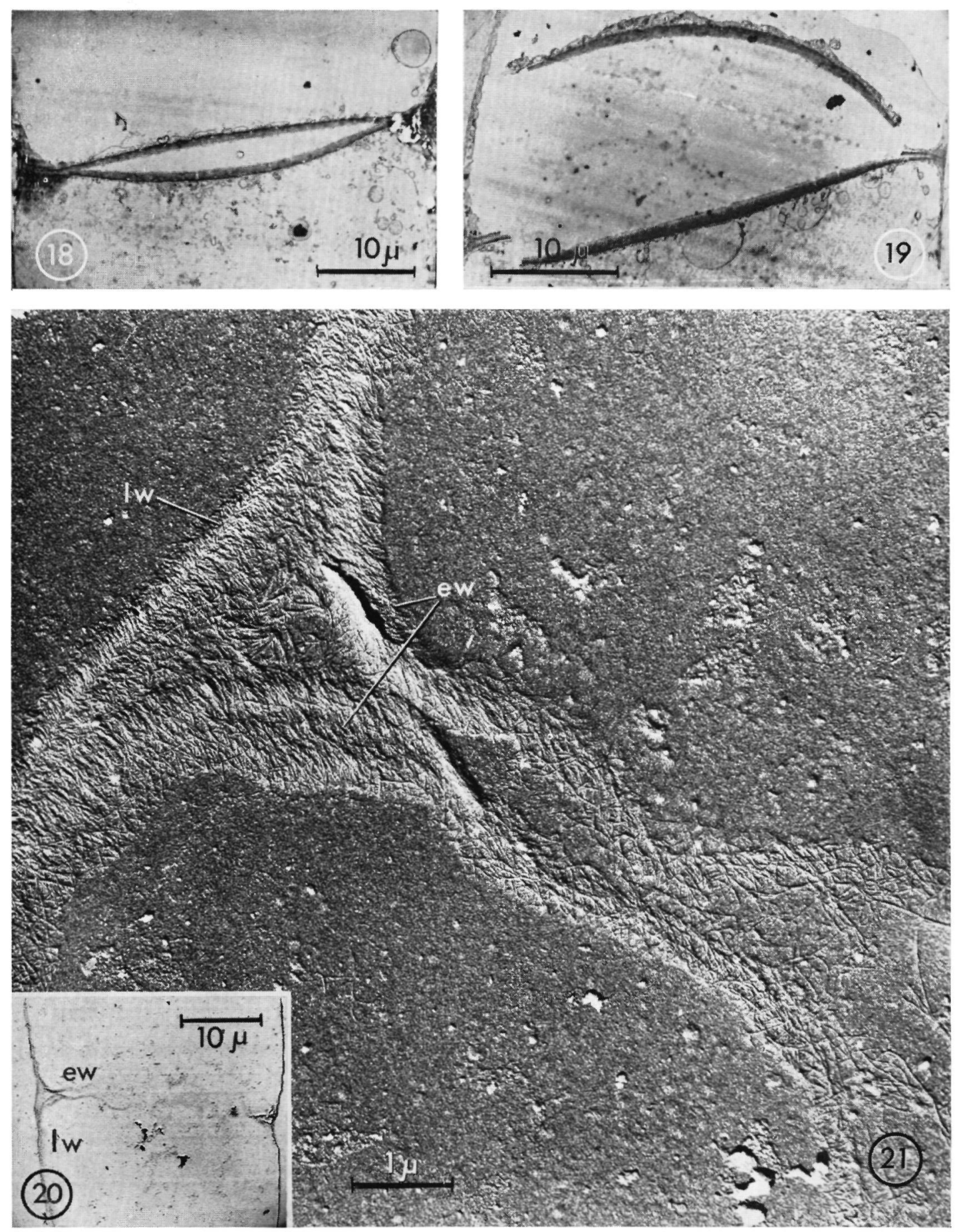

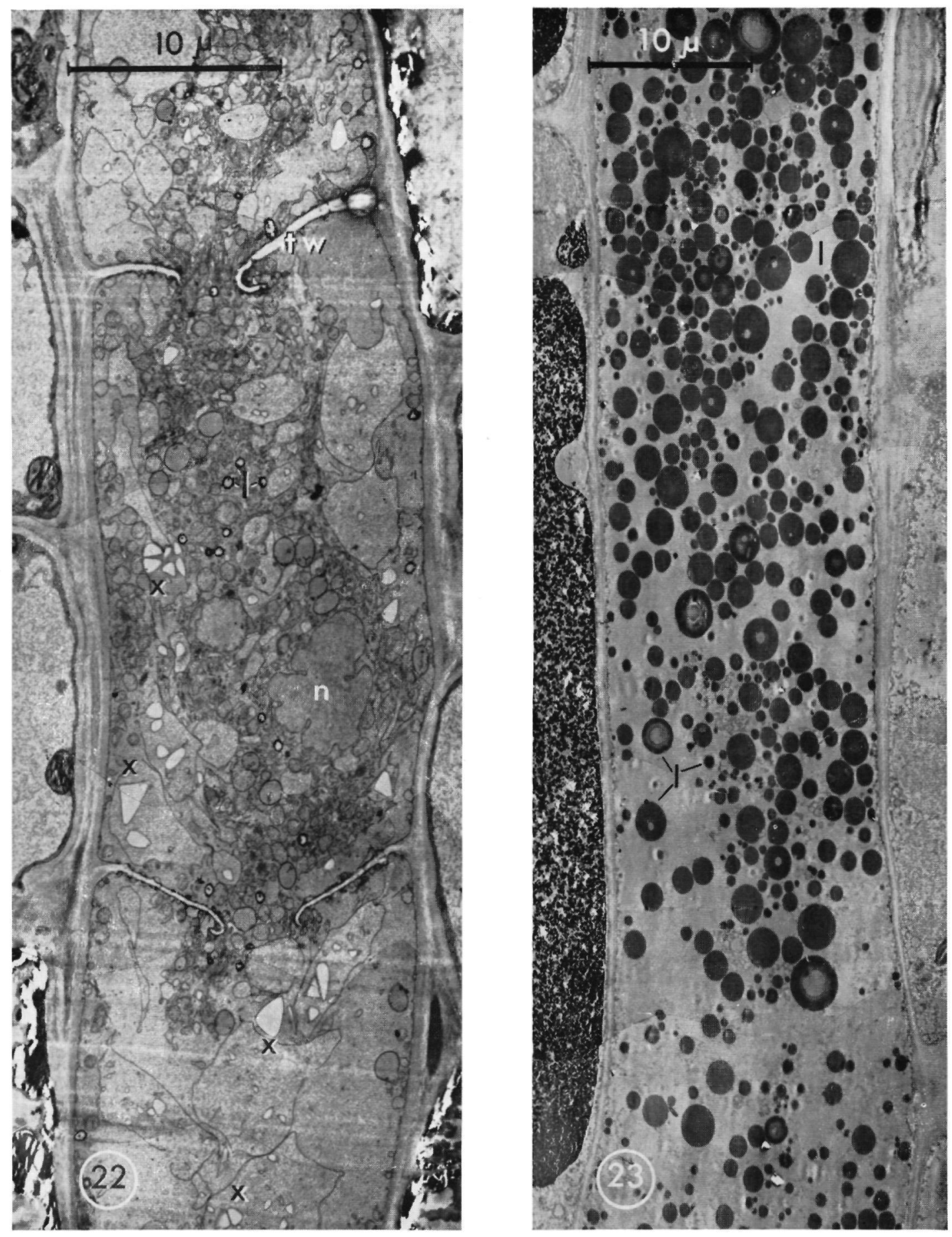


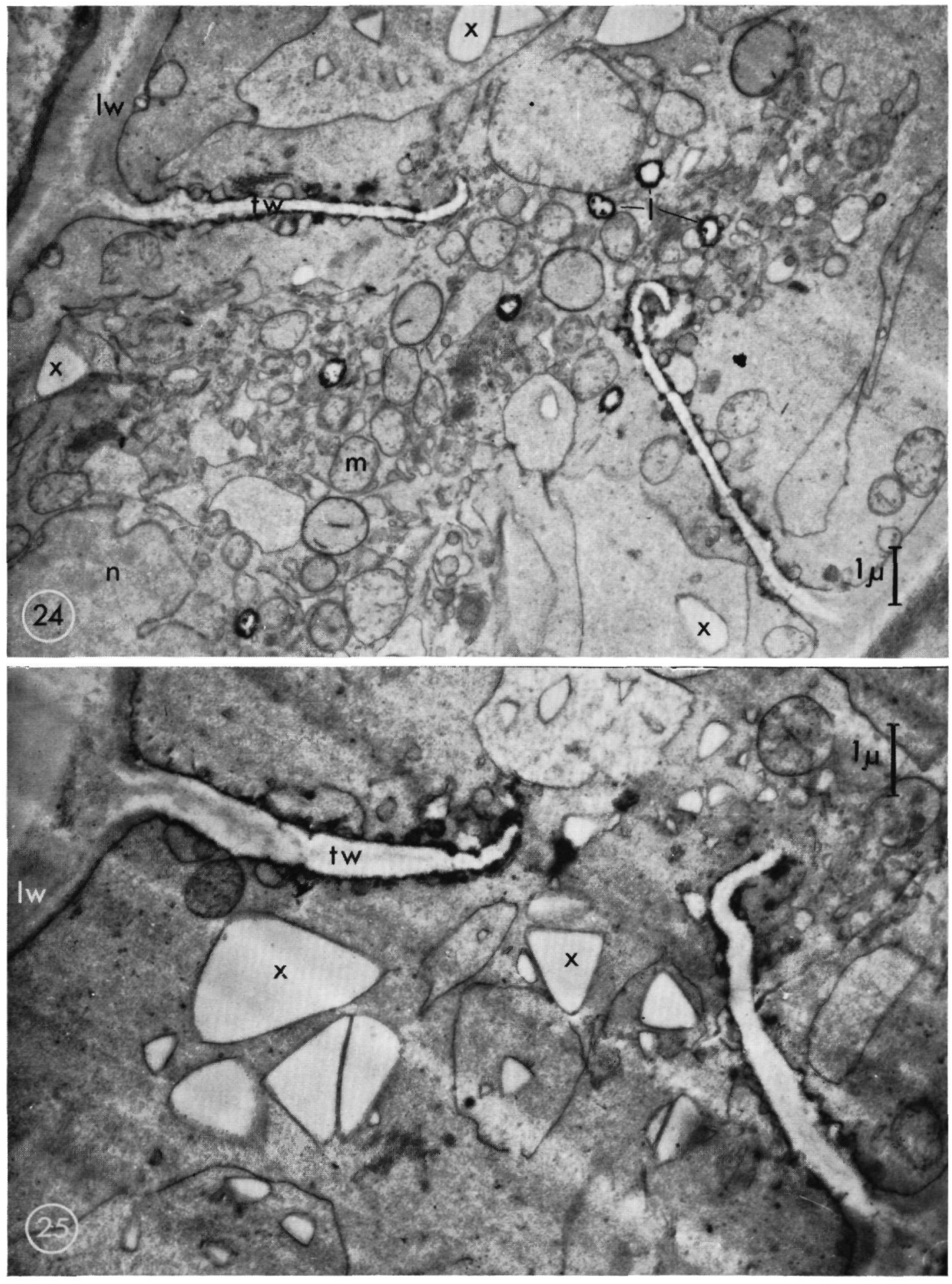




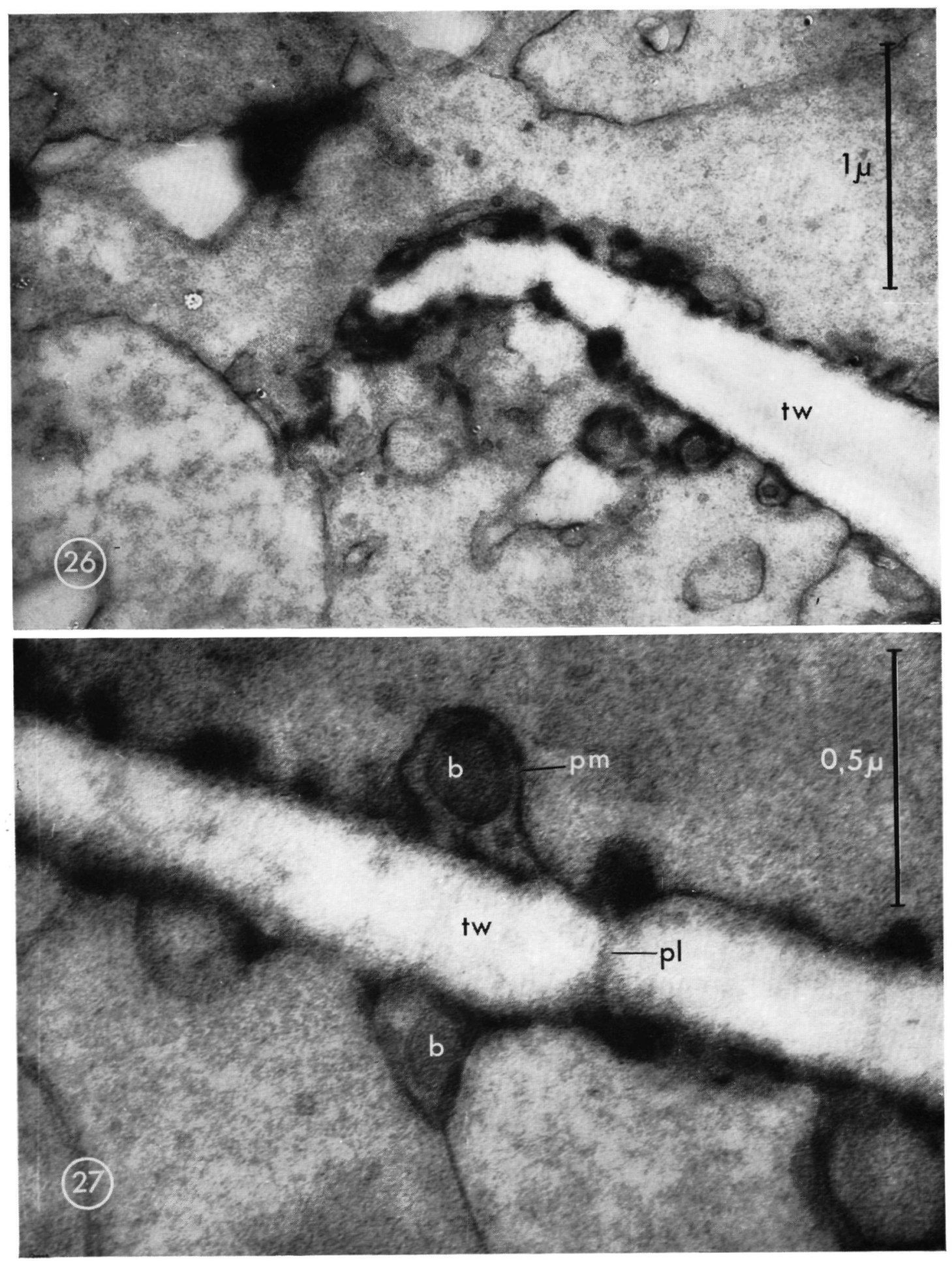




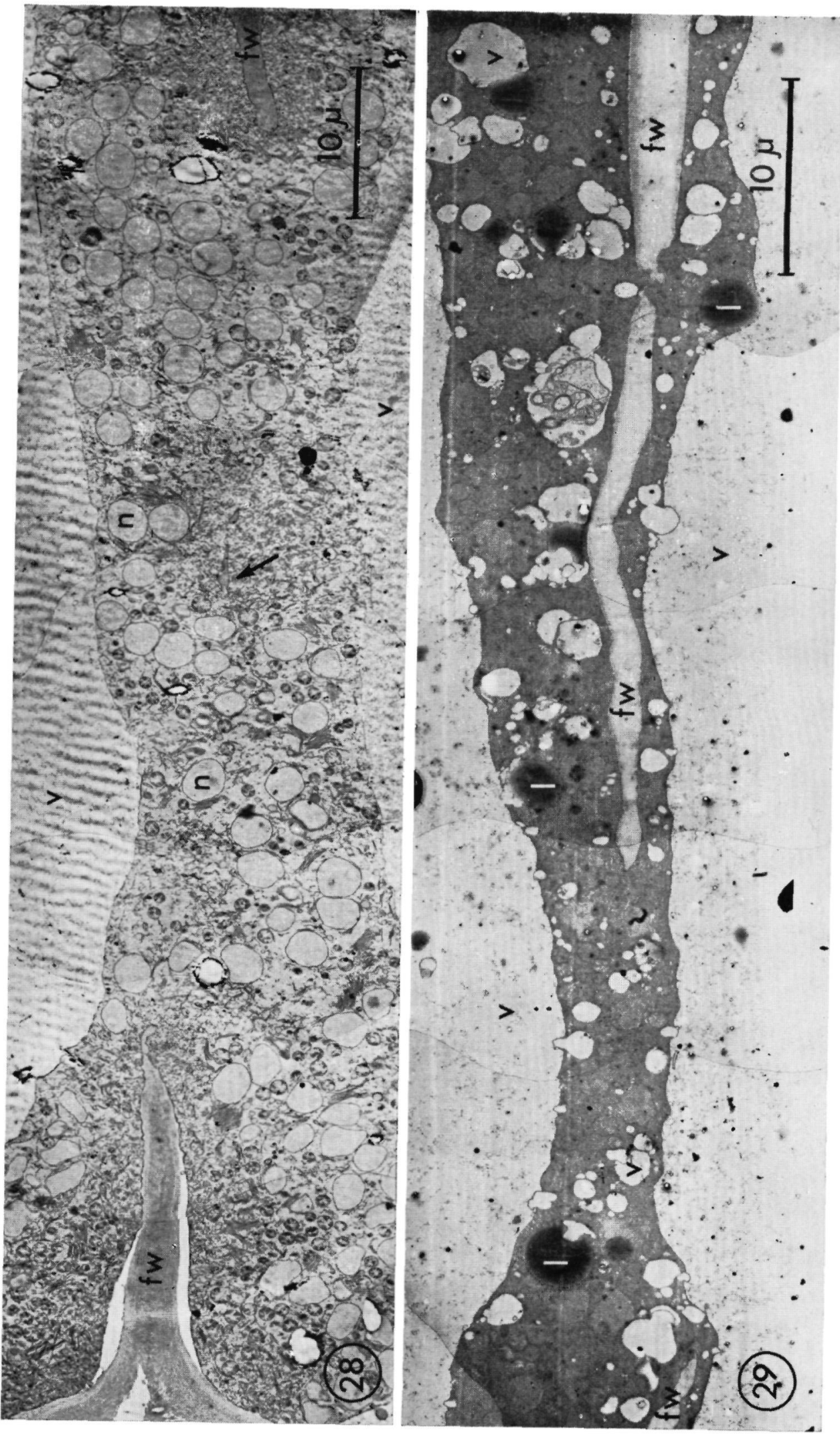



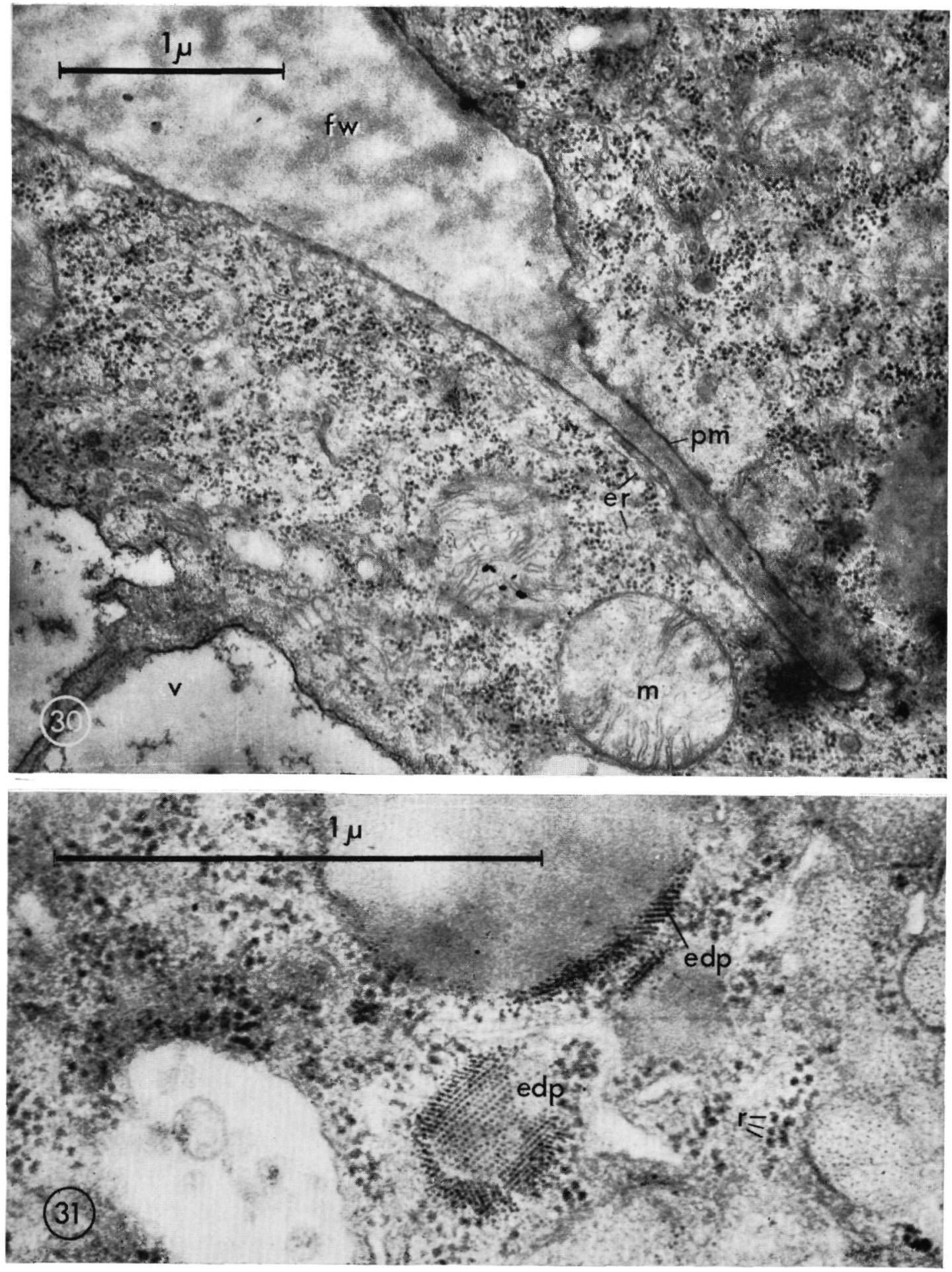


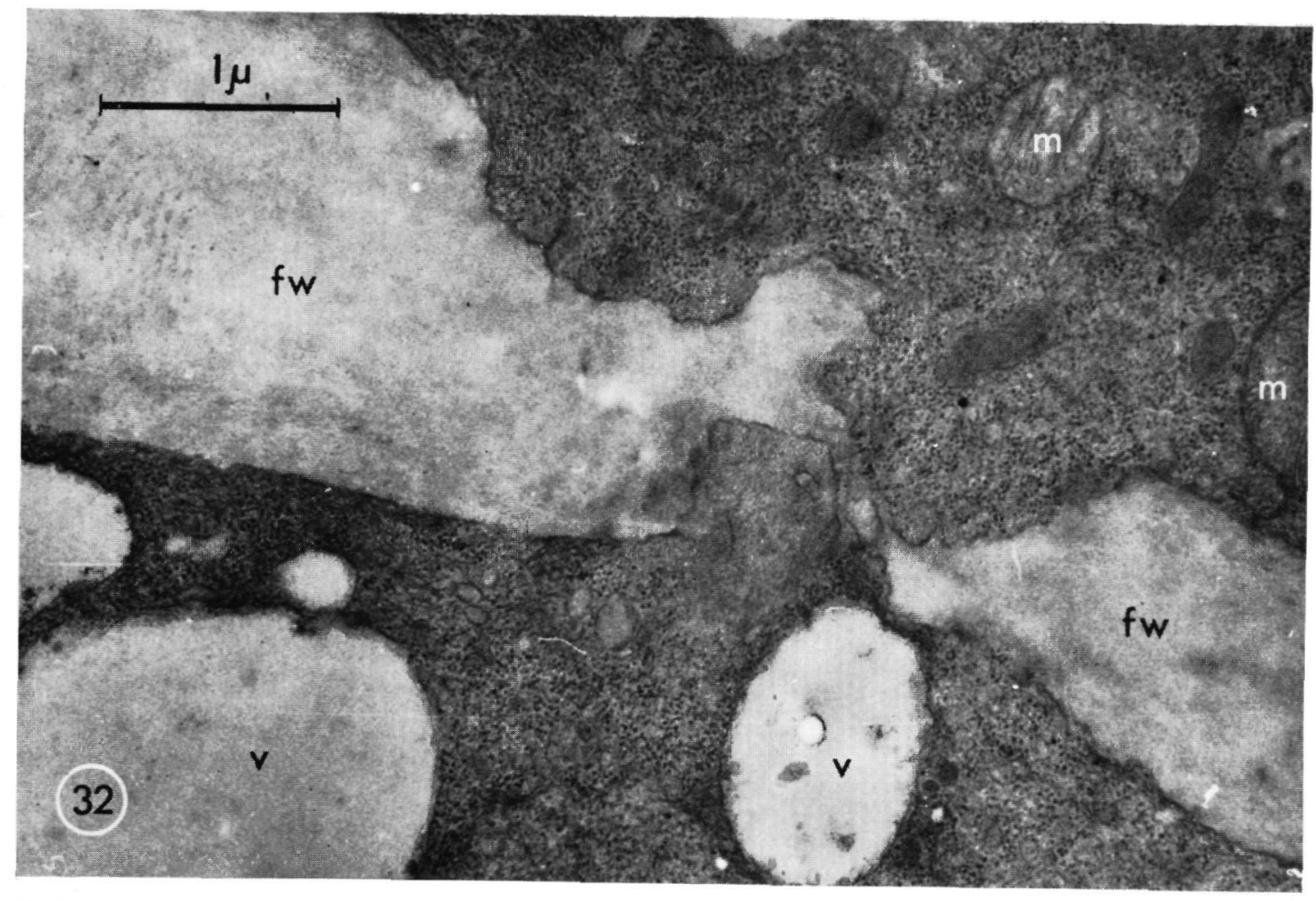

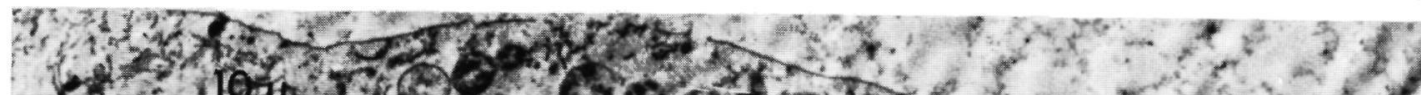
1. 3 in

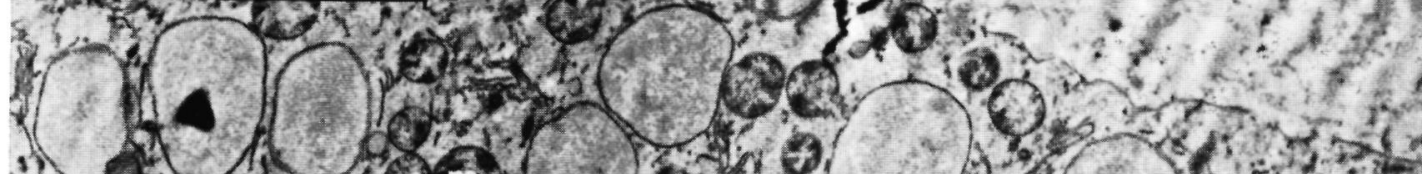

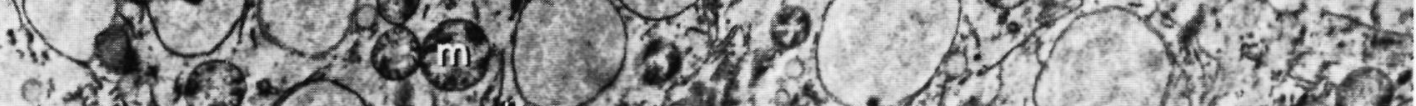

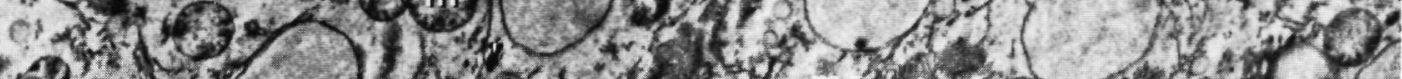

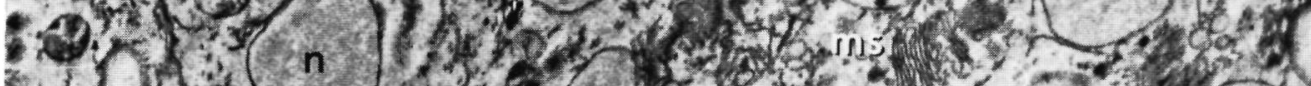

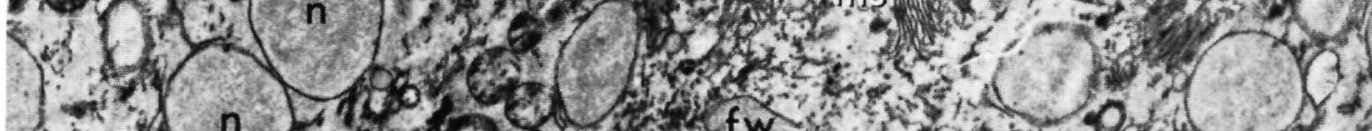

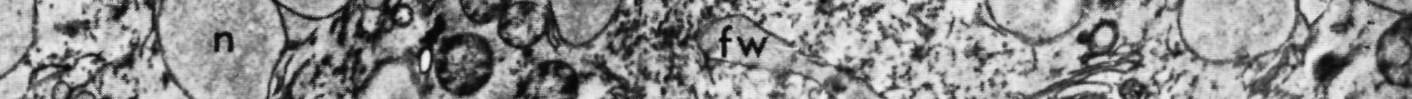

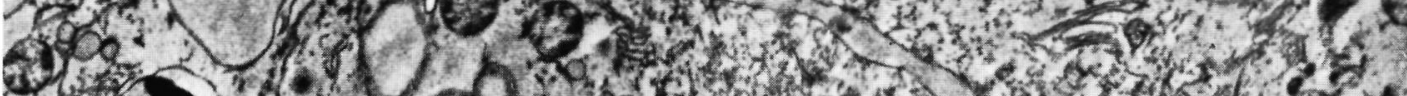

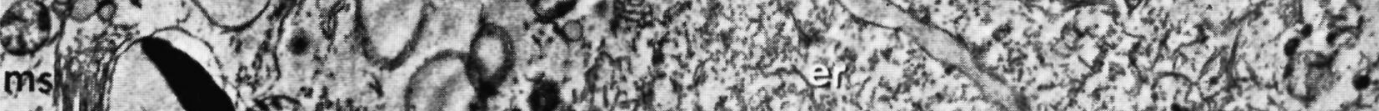

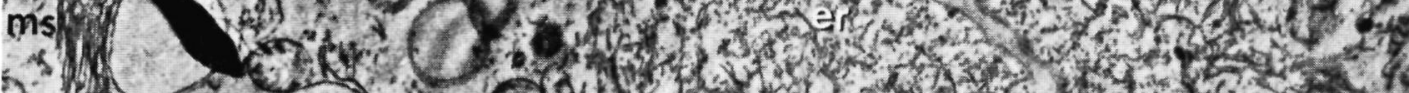

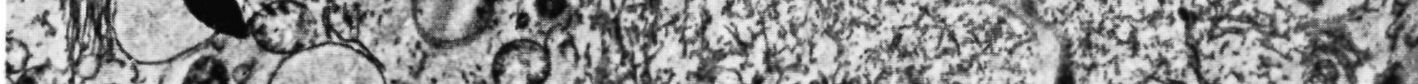
(2)

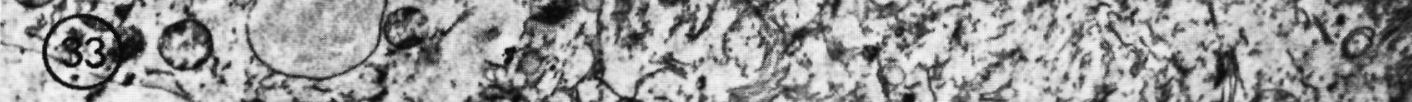

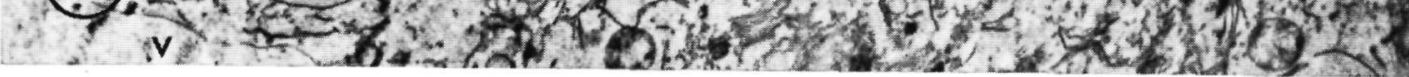




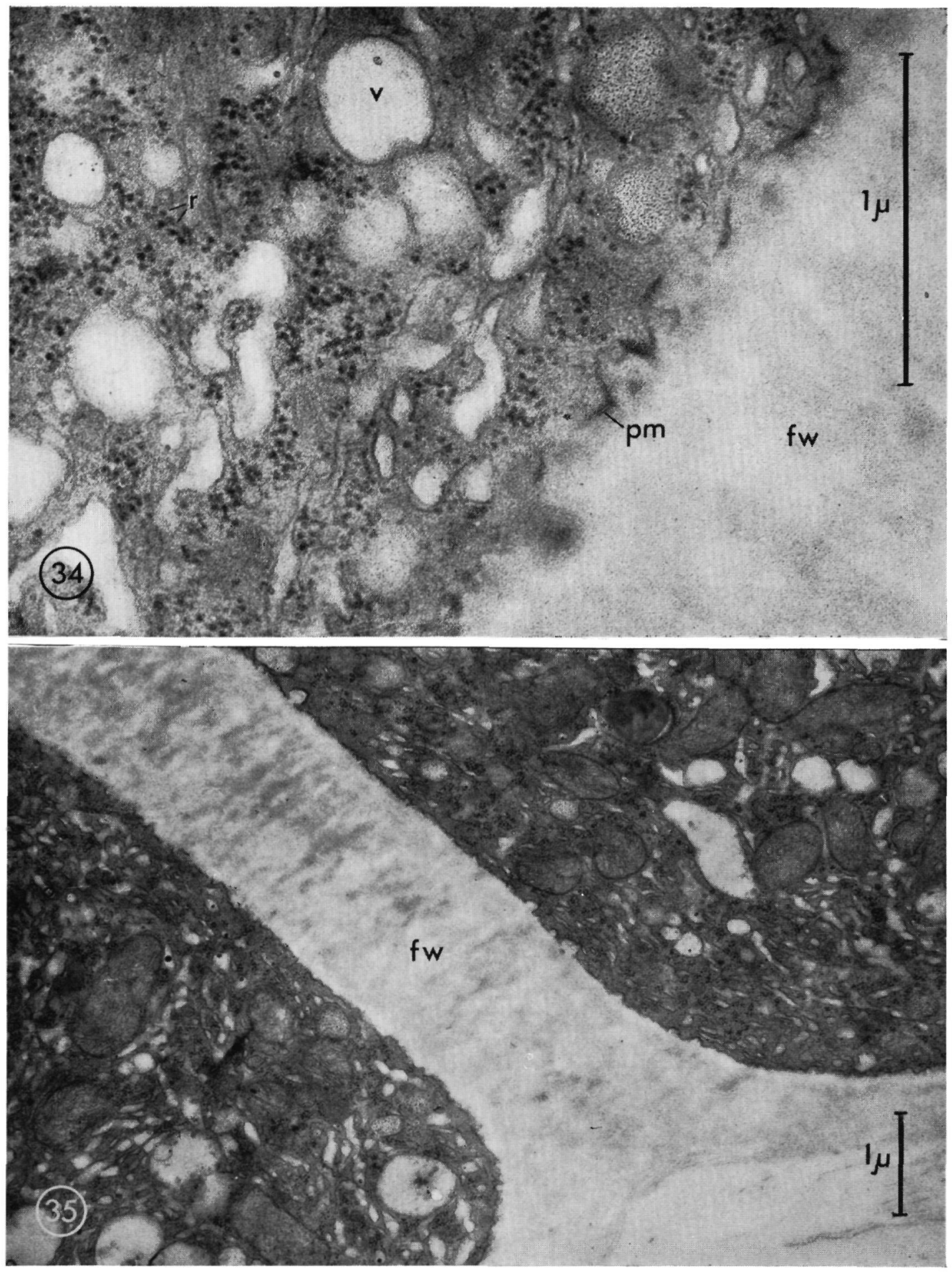




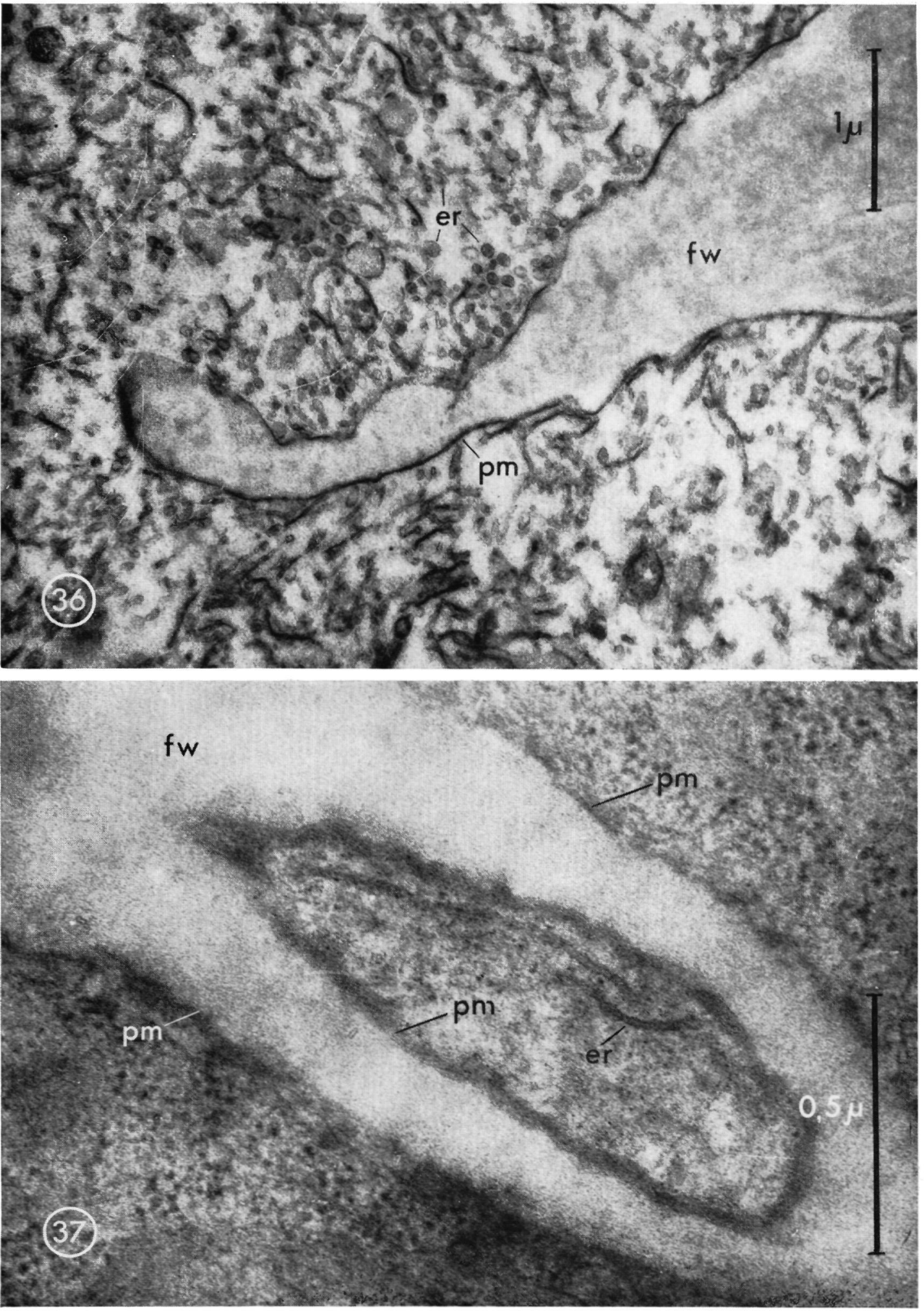



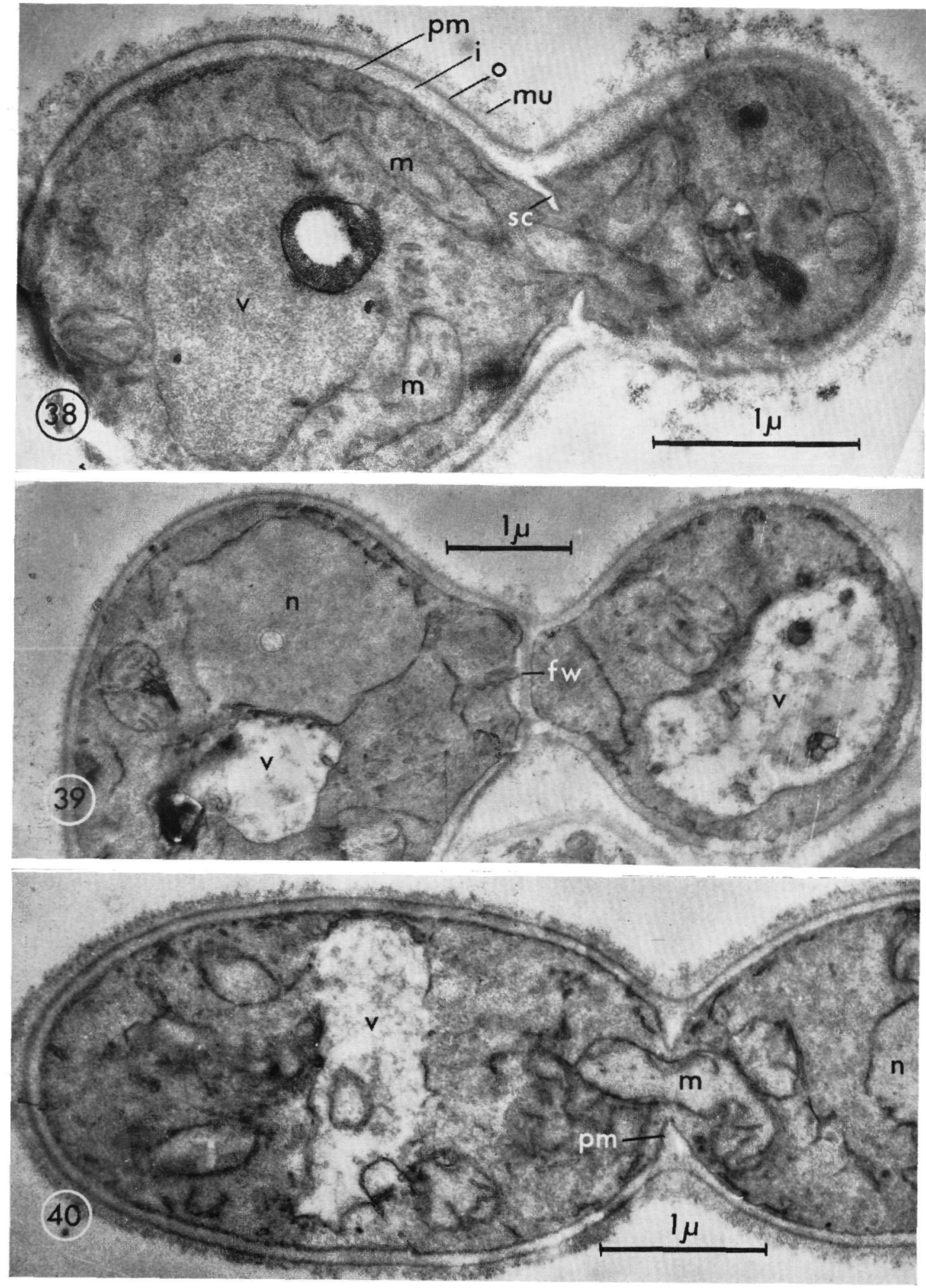

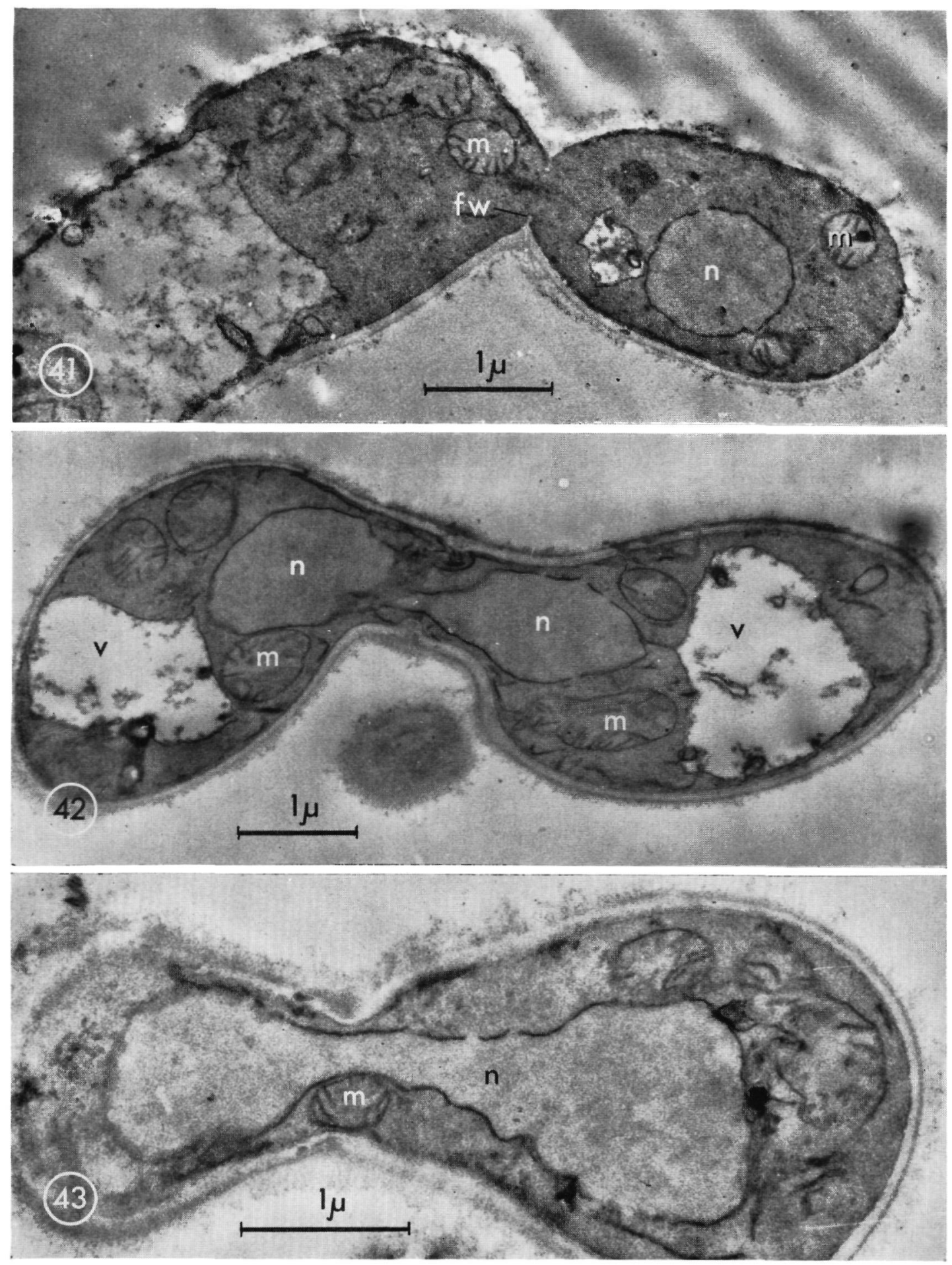


\section{STELLINGEN}

I

Tijdens differentiatie worden plantencelwanden die bij een celfusic bctrokken zijn in hun geheel enzymatisch afgebroken.

\section{II}

De opbouw zowel als de afbraak van de celwand in levende plantencellen vindt plaats door middel van enzymen die gelokalisecrd zijn aan de plasmamembraan.

\section{III}

Schimmels die via de cuticula in planten binnendringen doorboren deze cuticula enzymatisch en niet mechanisch.

\section{IV}

De voor het bestuderen van de microscopische bouw van plantenweefsels gebruikelijke term plantenanatomie kan beter vervangen worden door de term microscopische morfologie van de plant.

\section{$\mathrm{V}$}

De door Moor en Mühlethaler ontwikkelde "frceze-etching" methode heeft aangetoond dat de tot nu toe in de electronenmicroscopie gebruiktc fixeer- en inbedtechnicken betrouwbaar zijn.

H. Moor and K. Mühlethater. 1963. J. Cell Biol. 17: $609-628$.

\section{VI}

Er zijn gegevens die er op wijzen dat de schuifhypothese ter verklaring van het contractiemechanisme van spieren ontoereikend is.

J. W. SAnger and A. G. Szent-Györgyi. 1964. Biol. Bull. 127: 391.

\section{VII}

Er bestaat reden om aan te nemen dat er slechts één algemeen geldend mechanisme bestaat voor genetische recombinatie op moleculair niveau.

M. Meselson. 1963. Proc. XVI Int. Congr. Zool., Washington. 


\section{VIII}

De invoering van de innerlijkhcid als kenmerkend voor het leven vraagt consequent een toekennen van de innerlijkheid ook aan de anorganische materie.

Vergelijk: A. G. M. van Melsen. 1964. Evolutie en Wijsbegeerte, Het Spectrum N.V., Utrecht/ Antwerpen.

\section{IX}

Voor het wetenschappelijk onderzoek van de ruimte is het niet noodzakelijk om mensen aan gevaren in de ruimte bloot te stellen.

M. M. A. SASSEN

Nymegen 1965 
